\title{
Determinants of HPV vaccination intentions among Dutch girls and their mothers: a cross- sectional study
}

Hilde M van Keulen ${ }^{1 *}$, Wilma Otten ${ }^{1}$, Robert AC Ruiter ${ }^{2}$, Minne Fekkes ${ }^{1}$, Jim van Steenbergen ${ }^{3,4}$, Elise Dusseldorp ${ }^{1}$ and Theo WGM Paulussen ${ }^{1}$

\begin{abstract}
Background: The Dutch government recently added universal Human Papilloma Virus (HPV) vaccination for 12-year-old girls to the existing national immunization program. The participation rate for the initial catch-up campaign for girls aged 13 to 16 years in 2009 was lower (47\%) than expected (70\%). To inform future HPV information campaigns, this paper examines the social and psychological determinants of the HPV vaccination intentions of girls aged 13 to 16 years and their mothers who were targeted by the Dutch catch-up campaign of 2009.

Methods: A random sample of girls and their mothers was chosen from the Dutch vaccination register and received a letter inviting them to participate ( $\mathrm{n}=5,998$ mothers and daughters). In addition, a random sample was recruited via an online panel by a marketing research company ( $n=650$ mothers; $n=350$ daughters). Both groups were asked to complete a web-based questionnaire with questions on social demographic characteristics, social-psychological factors and HPV vaccination intention. Backward linear regression analyses were conducted to examine which social-psychological factors were most dominantly associated with vaccination intention.

Results: Data from 952 mothers (14\%) and 642 daughters (10\%) were available for the intended analyses. The contribution of social demographic variables to the explained variance of HPV vaccination intention was small but significant for mothers $\left(\Delta R^{2}=.01 ; p=.007\right)$, but not significant for daughters $\left(\Delta R^{2}=.02 ; p=.17\right)$ after controlling for $\mathrm{HPV}$ vaccination uptake and the sample. In addition, social-psychological determinants largely contributed to the explained variance of HPV vaccination intention of mothers $\left(\Delta R^{2}=.35 ; p<.001\right)$ and daughters $\left(\Delta R^{2}=.34 ; p<.001\right)$. Attitudes, beliefs, subjective norms and habit strength were significantly associated with participants' HPV vaccination intentions.

Conclusions: Because of the large contribution of social-psychological variables to the explained variance of HPV vaccination intentions among the mothers and daughters, future communication strategies targeting HPV vaccination uptake should address attitudes, beliefs, subjective norms and habit strength. There is a need for longitudinal research to confirm the causality of the association between these determinants and HPV vaccination behavior indicated by this study.
\end{abstract}

Keywords: HPV, Vaccination intention, Screening, Cancer, Social-psychological determinants

\footnotetext{
* Correspondence: hilde.vankeulen@tno.nl

${ }^{1}$ TNO (Netherlands Organization for Applied Scientific Research), Expertise

Center Life Style, PO Box 2215, Leiden 2301 CE, the Netherlands

Full list of author information is available at the end of the article
} 


\section{Background}

Despite a long-standing efficient national cervical cancer screening program for women aged 30 to 60 (uptake 66\%) [1], 600 new cases of cervical cancer are still diagnosed every year in the Netherlands, and 200 of these patients will eventually die from the disease [2]. The major cause of cervical cancer is persistent infection by the Human Papilloma Virus (HPV) [3], the most common sexually transmitted infection among young women [2,3]. Of all HPV types, types 16 and 18 are responsible for about $70 \%$ of cervical cancer cases [4,5]. To prevent persistent HPV infection, two vaccines have been licensed in Europe: Cervarix $^{\circledR}$ GSK and Gardasil ${ }^{\circledR}$. The Dutch Health Council estimated that the annual number of new cervical cancer cases in the Netherlands could be reduced by $50 \%$ by adding universal HPV vaccination of 12-year-old girls to the cervical cancer screening program [2]. The Dutch government decided to implement the Cervarix ${ }^{\circledR}$ GSK vaccine for this age group in the National Immunization Program (NIP), starting in 2010. Each year, the new cohort of 12-year-old girls will be invited to receive the HPV vaccination. The full schedule for this non-mandatory, free vaccine includes three injections (i.e., baseline, at one month and at six months).

In 2009, a HPV vaccination catch-up campaign was organized for girls born between 1993 and 1996 (at that time, 13 to 16 years of age). As with other NIP campaigns, this campaign was coordinated by the National Institute for Public Health and the Environment (RIVM). The accompanying information campaign consisted of an information pamphlet sent to the home addresses of the girls invited, a website with information about the HPV vaccination for girls and parents, and references to a help line. The Community Health Services, which is responsible for the local implementation of the $\mathrm{HPV}$ vaccination, organized local mass vaccination sites for girls.

The Dutch NIP, initially implemented in 1999, is one of the most cost-effective public health programs with a consistently high and stable vaccine coverage [6]. About 95\% of infants and young children in the Netherlands are vaccinated under the universal childhood vaccination program [7]. The expected participation rate for the HPV campaign was $70 \%$, for several reasons (e.g., the novelty of the vaccine, a new age group, the targeting only of girls and a vaccine targeting sexual transmitted infection) [8]. However, the 2009 participation rate turned out to be much lower, with $57 \%, 56 \%$ and $52 \%$ of the invited girls completing one, two, and three vaccinations, respectively [9]. The participation rate remained low in 2010 and 2011 (56\% and 54\%, respectively) [10,11].

In response to this rather low participation rate, research into the social-psychological determinants of the HPV vaccination decision was initiated to provide direction for the improvement of future HPV vaccine communication to girls and parents used by public health officials to improve vaccination uptake. Because dropout after the first HPV injection (i.e., those who received only one dose) was low in 2010 (5\%), these insights into the decision to receive the vaccination can be used to improve the total vaccination uptake. This paper reports on the outcomes of our research on the social-psychological determinants of the HPV vaccination intentions of girls and parents who were targeted by the Dutch catch-up campaign in 2009.

Because the HPV vaccine has only recently been introduced worldwide, most studies have focused on determinants of future acceptance of the HPV vaccination before implementation [12-15]. Reviews indicate that the following factors were most likely to be associated with future acceptance of the HPV vaccine: perceived effectiveness of the vaccine, perceived risks of the vaccine, perceived barriers (e.g., vaccine costs, concerns that the vaccine would promote adolescent sexual behavior), physicians' recommendations and the opinions of significant others (i.e., subjective norms) [12-15]. Only a few studies have examined determinants of HPV vaccination acceptance after implementation of the vaccine [16-20]. Most of the determinants found in studies conducted before implementation were confirmed empirically by the studies following implementation of the HPV vaccine [16-20]. However, studies conducted after implementation found additional factors: attitude, knowledge, perceived harm and perceived behavioral control [16-20].

Even after implementation of the HPV vaccine, determinants of intention to take the HPV vaccination among girls and parents who do not have to make the decision in the immediate future may differ from those who have actually made the decision and were asked whether they would make it again. Focusing on participants in the latter group is important, because it may improve the explained variance of $H P V$ vaccination intention.

The present study is one of the first to examine determinants of the HPV vaccination intentions among participants who made a decision about the HPV vaccination. In addition, this study is one of the first to examine the extent to which determinants contribute to the HPV vaccination intention. The participants were Dutch girls and their mothers who received an invitation for the first catch-up campaign in 2009.

Given the young age of the girls involved, most studies acknowledge that parents play a large role in their daughters' HPV vaccination decision [12,16-27]. Some of these studies specifically focused on mothers $[16,18,25]$. The present study focuses on the HPV vaccination intention of both mothers and girls in order to explore the possible differential impact of the determinants on their HPV vaccination decision making. The research 
question is as follows: what are the social psychological determinants of the HPV vaccination intentions of girls and their mothers who were targeted by the Dutch catch-up campaign in 2009?

\section{Methods}

This cross-sectional study used a quantitative retrospective approach by means of a web-based questionnaire offered to girls born in 1995 and 1996 (at that time, aged 13 and 14 years) who were invited for the catch-up HPV vaccination campaign in 2009 and their mothers. We recruited study participants among this youngest cohort only, because they best resembled the girls who will be targeted by future campaigns. This research conformed to the Helsinki Declaration and to local legislation. The study was exempt from ethical review according to the Independent Review Board Amsterdam, a medical ethics committee acknowledged by the Central Committee on Research Involving Human Subjects (CCMO).

The girls and their mothers received information about the study in the invitation letter. Those who chose to participate gave their informed consent by filling out the questionnaire. In the invitation letter and at the start of the questionnaire, participants were assured of their privacy, the confidentiality and security of responses, and informed that they could withdraw their participation at any time. Their responses were anonymized; the researchers were unable to verify participants' names, addresses and e-mail addresses. Participants accessed the online questionnaire by using a log-in code, a unique number. This number was only used by a third party contact person from Praeventis for the Praeventis sample and an online panel bureau for the online panel sample to send reminders to those who did not respond to the first invitation; see "Participants" section for more information about the samples. Participants who completed the questionnaire were not able to participate for a second time.

\section{Participants}

A flow diagram of the recruitment and response of participants is presented in Figure 1. The girls and mothers were invited to participate in the study from November 2009 until January 2010. At that time, those girls who agreed to take the HPV vaccination could have received three injections.

\section{Praeventis}

Participants were invited via Praeventis, the Dutch vaccination register hosted by RIVM. Mothers and daughters that were invited came from the same family unit. A computer program was used to draw a random sample of 6,000 addresses of girls born in 1995 or 1996 that was stratified on known geographical differences in vaccine uptake and ethnicity. Since the addresses of two participants were unknown, the study invitation was sent to 5,998 addresses. The invitation consisted of a single letter addressing mothers of girls born in 1995 or 1996 and the girls themselves. The invitation included a brief description of the study purpose, information about anonymity of participation, a log-in number and an explanation of the log-in procedure.

The online questionnaire for the Praeventis sample was hosted on a private part of the TNO website, which was only accessible through use of the log-in number. Computer assisted self-interviewing was used for the online questionnaire and participants were not rewarded for filling out the questionnaire. The questionnaire was open for response from November 30, 2009, until January 10, 2010. Mothers and daughters ( $\mathrm{n}=5,929 ; 99 \%)$ who had not responded within three weeks after the first invitation received a reminder. Of the 5,998 invited participants from Praeventis, 564 mothers (9\%) and 537 daughters (9\%) started the questionnaire, of which 445 mothers (79\%) and 404 daughters (75\%) fully completed the survey. A large percentage of mothers and daughters who started (21\% and $25 \%$, respectively) failed to complete the questionnaire. Male participants $(n=5)$ and those with an invalid age $(n=4)$ were excluded from the analyses. The final response rate was $7 \%(\mathrm{~N}=441)$ among the mothers, and $7 \%(\mathrm{~N}=399)$ among the daughters.

\section{Online panel}

Due to the Praeventis sample's limited response to the first invitation letter, we decided to recruit an extra sample by using an online panel of a private marketing research company. A computer program was used to draw a random sample of 650 mothers of girls born in 1995 or 1996, and 350 of their daughters that was stratified on age, education and geographical differences in vaccine uptake. Among the online panel sample, 350 invited mothers and daughters came from the same family unit. They were sent an e-mail that offered the opportunity to complete the questionnaire between December 18 and December 24, 2009. The online panel was responsible for collecting the data among the sample and TNO was owner of the data. Computer assisted self-interviewing was used for the online questionnaire, which was hosted on a private part of the online panel website that was only accessible through use of the log-in number. Participants from the online panel sample were rewarded for completing the questionnaire according to the standards of the online panel company: they received panel points that could be exchanged for gift coupons. The points that each participant received for completing the questionnaire about HPV vaccination were worth 4.35 euros. The response rate of people contacted by this recruitment strategy was $79 \%(\mathrm{~N}=511)$ among the mothers, and $69 \%$ $(\mathrm{N}=243)$ among the daughters. 


\section{Praeventis random sample}

Dutch addresses $(n=6,000)$ of girls born in 1995 or 1996 stratified by ethnicity and vaccine uptake.

\section{Ethnicity:}

- 3,300 general sample;

- 2,700 selected sample of which 900 per ethnical group (Turkey, Morocco, and Surinam/Antilles).

Vaccine uptake per general/selected sample:

- One third with girls with $\geq 1$ HPV injection;

- $\quad$ Two thirds with girls with 0 injections.

Excluded $(\mathrm{n}=2$; unknown address)

\section{Excluded}

Mothers $(n=4)$ : male $(n=3)$, invalid age $(n=1)$

Daughters $(n=5)$ : male $(n=2)$, invalid age $(n=3)$
Online panel random sample

Mothers of girls born in 1995 or $1996(n=650)$

Daughters ( $\mathrm{n}=350$ of the sample of mothers)

Started with survey

Mothers $(n=564)$

Daughters $(\mathrm{n}=537)$

Completed survey

Mothers $(n=445)$

Daughters $(n=404)$

Completed survey

Mothers $(\mathrm{n}=511)$

Daughters $(n=243)$
Received invitation

Mothers $(\mathrm{n}=650)$

Daughters $(\mathrm{n}=350)$
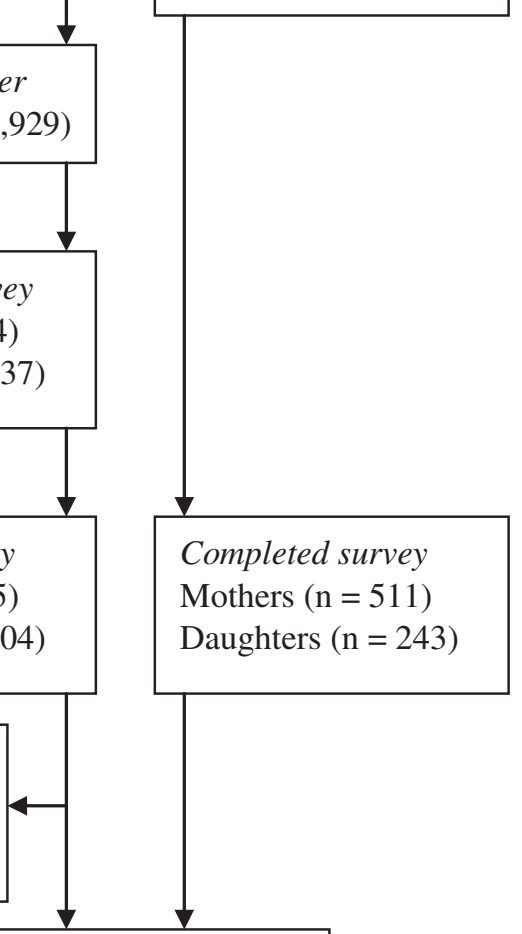

Data available for analyses

Mothers $(\mathrm{n}=952)$

Daughters $(n=642)$

Figure 1 Flow diagram of the recruitment and response of study participants.

In total, data from 952 mothers (14\%) and 642 of their daughters $(10 \%)$ were available for the intended analyses. The total sample included 497 mother-daughter pairs, and 455 and 145 independent mothers and daughters, respectively.

\section{Questionnaire}

The online questionnaire was based on information derived from former empirical research on general vaccination intention, HPV vaccination intention (see Table 1 for references) and qualitative focus groups with representatives 
Table 1 Overview of social-psychological scale measures ${ }^{1}$

\begin{tabular}{|c|c|c|c|c|c|c|}
\hline Measure & Item & Answer options & $\begin{array}{l}\text { Scale (minimum to } \\
\text { maximum value) }\end{array}$ & $\begin{array}{l}\text { Number } \\
\text { of items }\end{array}$ & $\begin{array}{l}\text { Cronbach's } \\
\text { alpha (a) }\end{array}$ & Reference \\
\hline \multirow{8}{*}{$\begin{array}{l}\text { Knowledge about } \\
\text { the HPV } \\
\text { vaccination }\end{array}$} & - HPV is sexually transmittable; & $-1=$ incorrect & $-8=$ incorrect & 8 & $\mathrm{n} / \mathrm{a}$ & \\
\hline & - HPV is a virus; & $0=$ don't know & $8=$ correct & & & \\
\hline & $\begin{array}{l}\text { - The HPV vaccination in the Netherlands } \\
\text { consists of three injections; }\end{array}$ & \multirow[t]{6}{*}{$1=$ correct } & & & & \\
\hline & $\begin{array}{l}\text { - My daughter is/l am obliged to get the } \\
\text { HPV vaccination when she is/l am invited; }\end{array}$ & & & & & \\
\hline & $\begin{array}{l}\text { - You will always notice when you are } \\
\text { infected by HPV; }\end{array}$ & & & & & \\
\hline & - Only women can get infected by HPV; & & & & & \\
\hline & $\begin{array}{l}\text { - Women who received the HPV vaccination } \\
\text { are still advised to participate in the cervical } \\
\text { cancer screening in the Netherlands; }\end{array}$ & & & & & \\
\hline & $\begin{array}{l}\text { - The HPV vaccination fully protects } \\
\text { against cervical cancer. }\end{array}$ & & & & & \\
\hline $\begin{array}{l}\text { Risk perception } \\
\text { (having received } \\
\text { no HPV vaccination) }\end{array}$ & $\begin{array}{l}\text { Imagine that your daughter was/you were not } \\
\text { vaccinated against HPV. The chance that my } \\
\text { daughter will get/I will get cervical cancer is... }\end{array}$ & $\begin{array}{l}-3=\text { very small } \\
\text { to } 3=\text { very large }\end{array}$ & $\mathrm{n} / \mathrm{a}$ & 1 & $\mathrm{n} / \mathrm{a}$ & {$[20,31]$} \\
\hline $\begin{array}{l}\text { Risk perception } \\
\text { (having received } \\
\text { the HPV vaccination) }\end{array}$ & $\begin{array}{l}\text { Imagine that your daughter was/you were } \\
\text { vaccinated against HPV. The chance that my } \\
\text { daughter will get/I will get cervical cancer is... }\end{array}$ & $\begin{array}{l}-3=\text { very small } \\
\text { to } 3=\text { very large }\end{array}$ & $\mathrm{n} / \mathrm{a}$ & 1 & $\mathrm{n} / \mathrm{a}$ & {$[20,31]$} \\
\hline \multirow{5}{*}{$\begin{array}{l}\text { Attitude towards } \\
\text { the HPV vaccination }\end{array}$} & \multirow{5}{*}{$\begin{array}{l}\text { Vaccinating my daughter/myself against } \\
\text { HPV is... }\end{array}$} & \multirow{2}{*}{$\begin{array}{l}-3=\text { very undesirable } \\
\text { to } 3=\text { very desirable; }\end{array}$} & \multirow{5}{*}{$\begin{array}{l}-12=\text { negative } \\
\text { to } 12=\text { positive }\end{array}$} & \multirow[t]{5}{*}{4} & $M=.98$ & \multirow[t]{5}{*}[31]{} \\
\hline & & & & & $\mathrm{D}=.94$ & \\
\hline & & $\begin{array}{l}-3=\text { very bad } \\
\text { to } 3=\text { very good; }\end{array}$ & & & & \\
\hline & & $\begin{array}{l}-3=\text { very negative } \\
\text { to } 3=\text { very positive; }\end{array}$ & & & & \\
\hline & & $\begin{array}{l}-3=\text { very } \\
\text { unimportant to } \\
3=\text { very important }\end{array}$ & & & & \\
\hline \multirow{6}{*}{$\begin{array}{l}\text { Negative outcome } \\
\text { expectations of the } \\
\text { HPV vaccination }\end{array}$} & $\begin{array}{l}\text { If my daughter gets/l get the HPV } \\
\text { vaccination... }\end{array}$ & \multirow{6}{*}{$\begin{array}{l}-3=\text { completely } \\
\text { agree to } 3= \\
\text { completely disagree }\end{array}$} & \multirow{6}{*}{$\begin{array}{l}-15=\text { completely } \\
\text { agree to } \\
15=\text { completely } \\
\text { disagree }\end{array}$} & \multirow[t]{6}{*}{5} & \multirow{6}{*}{$\begin{array}{l}M=.60 \\
D=.49\end{array}$} & \multirow[t]{6}{*}[20,27,32]{} \\
\hline & - she/l will become infertile; & & & & & \\
\hline & $\begin{array}{l}\text { - she/l will get unpleasant side effects shortly } \\
\text { after the injection, such as head ache, fever } \\
\text { or pain at the injection spot; }\end{array}$ & & & & & \\
\hline & $\begin{array}{l}\text { - she/l will be afraid of the injection with } \\
\text { a needle; }\end{array}$ & & & & & \\
\hline & - she/l will have unsafe sex in the future; & & & & & \\
\hline & $\begin{array}{l}\text { - her/my natural immune system against } \\
\text { illnesses will be disturbed. }\end{array}$ & & & & & \\
\hline \multirow{5}{*}{$\begin{array}{l}\text { Positive outcome } \\
\text { expectations of the } \\
\text { HPV vaccination }\end{array}$} & If my daughter gets/I get the HPV & \multirow{5}{*}{$\begin{array}{l}-3=\text { completely } \\
\text { disagree to } 3= \\
\text { completely agree }\end{array}$} & \multirow{5}{*}{$\begin{array}{l}-9=\text { completely } \\
\text { disagree to } 9= \\
\text { completely agree }\end{array}$} & \multirow[t]{5}{*}{3} & \multirow{5}{*}{$\begin{array}{l}M=.76 \\
D=.77\end{array}$} & \multirow[t]{5}{*}[33,34]{} \\
\hline & tion... & & & & & \\
\hline & - she/l will not contract cervical cancer; & & & & & \\
\hline & $\begin{array}{l}\text { - she/l will not have to worry about } \\
\text { cervical cancer; }\end{array}$ & & & & & \\
\hline & - she/l will not be infected with HPV. & & & & & \\
\hline $\begin{array}{l}\text { Anticipated regret } \\
\text { about rejecting the } \\
\text { HPV vaccination }\end{array}$ & $\begin{array}{l}\text { Imagine your daughter has not received the } \\
\text { HPV vaccination and she gets cervical cancer } \\
\text { in the future. How much would you regret } \\
\text { your decision to let her receive no vaccination? }\end{array}$ & $\begin{array}{l}1=\text { no regret and } \\
5=\text { very much } \\
\text { regret }\end{array}$ & $\mathrm{n} / \mathrm{a}$ & 1 & $\mathrm{n} / \mathrm{a}$ & \\
\hline $\begin{array}{l}\text { Anticipated regret } \\
\text { about receiving the } \\
\text { HPV vaccination }\end{array}$ & $\begin{array}{l}\text { Imagine your daughter has received the HPV } \\
\text { vaccination and she gets a serious illness as } \\
\text { a result of the vaccine. How much would }\end{array}$ & $\begin{array}{l}1=\text { no regret and } \\
5=\text { very much } \\
\text { regret }\end{array}$ & $\mathrm{n} / \mathrm{a}$ & 1 & $\mathrm{n} / \mathrm{a}$ & \\
\hline
\end{tabular}




\section{Table 1 Overview of social-psychological scale measures ${ }^{1}$ (Continued)}

\begin{tabular}{|c|c|c|c|c|c|}
\hline & $\begin{array}{l}\text { you regret your decision to let her receive } \\
\text { the vaccination? }\end{array}$ & & & & \\
\hline \multirow{11}{*}{$\begin{array}{l}\text { Beliefs about the } \\
\text { HPV vaccination }\end{array}$} & \multirow{2}{*}{$\begin{array}{l}\text { - If the government offers the vaccination, } \\
\text { I assume it will be safe; }\end{array}$} & \multirow{2}{*}{$\begin{array}{l}-3=\text { completely } \\
\text { disagree to } 3= \\
\text { completely agree }\end{array}$} & \multirow{11}{*}{$\begin{array}{l}-18=\text { negative } \\
\text { to } 18=\text { positive }\end{array}$} & \multirow[t]{11}{*}{9} & $M=.80$ \\
\hline & & & & & $\mathrm{D}=.70$ \\
\hline & $\begin{array}{l}\text { - Our government shows responsibility for } \\
\text { the health of the Dutch population by } \\
\text { introducing the HPV vaccination; }\end{array}$ & \multirow[t]{9}{*}{$\begin{array}{l}-3=\text { completely } \\
\text { agree to } 3= \\
\text { completely disagree }\end{array}$} & & & \\
\hline & $\begin{array}{l}\text { - The HPV vaccination was only introduced } \\
\text { because the pharmaceutical industry will } \\
\text { earn a lot of money from it; }\end{array}$ & & & & \\
\hline & - There is too little known about whether & & & & \\
\hline & $\begin{array}{l}\text { the HPV vaccination effectively protects } \\
\text { against cervical cancer; }\end{array}$ & & & & \\
\hline & $\begin{array}{l}\text { - There is too little known about the } \\
\text { detrimental side effects of the HPV } \\
\text { vaccination; }\end{array}$ & & & & \\
\hline & $\begin{array}{l}\text { - My daughter is/I am too young to } \\
\text { receive the HPV vaccination; }\end{array}$ & & & & \\
\hline & $\begin{array}{l}\text { - My daughter does/l do not need to } \\
\text { get the HPV vaccination if she is/I am } \\
\text { already sexually active; }\end{array}$ & & & & \\
\hline & $\begin{array}{l}\text { - My daughter does/I do not need the } \\
\text { vaccination because she is/l am not } \\
\text { yet sexually active; }\end{array}$ & & & & \\
\hline & $\begin{array}{l}\text { - It is inappropriate that my daughter } \\
\text { has/l have to pay for the HPV vaccination } \\
\text { if she decides/I decide to get the } \\
\text { vaccination at a higher age. }\end{array}$ & & & & \\
\hline \multirow[t]{7}{*}{$\begin{array}{l}\text { Relative effectiveness } \\
\text { of the HPV } \\
\text { vaccination }^{\text {b }}\end{array}$} & $\begin{array}{l}\text { How would you rate the effectiveness of } \\
\text { the following methods of preventing } \\
\text { cervical cancer: }\end{array}$ & \multirow[t]{7}{*}{$\begin{array}{l}1=\text { not at all } \\
\text { effective to } 10= \\
\text { very effective }\end{array}$} & \multirow[t]{7}{*}{$\mathrm{n} / \mathrm{a}$} & \multirow[t]{7}{*}{5} & \multirow[t]{7}{*}{$\mathrm{n} / \mathrm{a}$} \\
\hline & - having safe sex & & & & \\
\hline & $\begin{array}{l}\text { - having sex with only one person in } \\
\text { a lifetime }\end{array}$ & & & & \\
\hline & - participating in the cervical cancer screening & & & & \\
\hline & - having a healthy lifestyle (e.g. not smoking) & & & & \\
\hline & - the HPV vaccination & & & & \\
\hline & $\begin{array}{l}\text { Participants rated the effectiveness of } \\
\text { each method }\end{array}$ & & & & \\
\hline \multirow{5}{*}{$\begin{array}{l}\text { Ambivalence towards } \\
\text { the HPV vaccination } \\
\text { decision }\end{array}$} & \multirow{2}{*}{$\begin{array}{l}\text { During my decision making about } \\
\text { my daughter's/my HPV vaccination... }\end{array}$} & \multirow{5}{*}{$\begin{array}{l}-3=\text { completely } \\
\text { disagree to } 3= \\
\text { completely agree }\end{array}$} & \multirow{5}{*}{$\begin{array}{l}-9=\text { completely } \\
\text { disagree to } 9= \\
\text { completely agree }\end{array}$} & \multirow[t]{5}{*}{3} & $M=.93$ \\
\hline & & & & & \multirow[t]{4}{*}{$\mathrm{D}=.85$} \\
\hline & $\begin{array}{l}\text { - I felt torn between the pros and cons } \\
\text { of vaccination; }\end{array}$ & & & & \\
\hline & $\begin{array}{l}\text { - I experienced positive as well as } \\
\text { negative feelings; }\end{array}$ & & & & \\
\hline & $\begin{array}{l}\text { - I was torn between the pros and } \\
\text { cons of vaccination. }\end{array}$ & & & & \\
\hline \multirow{4}{*}{$\begin{array}{l}\text { Confidence in } \\
\text { authorities involved } \\
\text { in the HPV } \\
\text { vaccination }\end{array}$} & As regards the HPV vaccination, how & \multirow{4}{*}{$\begin{array}{l}-3=\text { very little } \\
\text { to } 3 \text { = very much } \\
\text { confidence }\end{array}$} & \multirow{4}{*}{$\begin{array}{l}-9=\text { very little } \\
\text { to } 9=\text { very much } \\
\text { confidence }\end{array}$} & \multirow[t]{4}{*}{3} & \multirow{4}{*}{$\begin{array}{l}\mathrm{M}=.91 \\
\mathrm{D}=.88\end{array}$} \\
\hline & - science & & & & \\
\hline & - health care & & & & \\
\hline & - the Ministry of Public Health & & & & \\
\hline
\end{tabular}




\section{Table 1 Overview of social-psychological scale measures ${ }^{1}$ (Continued)}

\begin{tabular}{|c|c|c|c|c|c|c|}
\hline & $\begin{array}{l}\text { Participants rated their confidence in } \\
\text { each authority }\end{array}$ & & & & & \\
\hline \multirow{6}{*}{$\begin{array}{l}\text { Subjective norms } \\
\text { towards the HPV } \\
\text { vaccination }^{c}\end{array}$} & Normative beliefs & \multirow{2}{*}{$\begin{array}{l}-2=\text { certainly not } \\
\text { vaccinating to } \\
2=\text { certainly } \\
\text { vaccinating, }\end{array}$} & $-70=$ negative to & $M=7$ & $M=.85$ & \multirow[t]{4}{*}[31]{} \\
\hline & $\begin{array}{l}\text { What is your expectation on the opinion } \\
\text { of ... about the HPV vaccination of } \\
\text { your daughter? }\end{array}$ & & 70 = positive $(M)$ & \multirow{3}{*}{$D=6$} & $\mathrm{D}=.77$ & \\
\hline & & 3 = not applicable; & \multirow{4}{*}{$\begin{array}{l}-60=\text { negative to } \\
60=\text { positive }(D)\end{array}$} & & & \\
\hline & $\begin{array}{l}\text { Social referents: partner }(M) \text {, parents }(M) \text {, } \\
\text { daughter }(M) \text {, father }(D), \text { mother }(D), \text { best } \\
\text { friends }(M / D) \text {, general practitioner }(M / D) \text {, } \\
\text { doctor/nurse from the municipal health } \\
\text { service (M/D), the Ministry of Public } \\
\text { Health (MD) }\end{array}$ & $\begin{array}{l}\text { Not applicable was } \\
\text { recoded into '0' }\end{array}$ & & & & \\
\hline & Motivation to comply & \multirow{2}{*}{$\begin{array}{l}1=\text { not at all to } \\
5=\text { very much }\end{array}$} & & \multicolumn{2}{|l|}{$M=7$} & \multirow[t]{2}{*}{ [31] } \\
\hline & $\begin{array}{l}\text { How motivated are you to comply with } \\
\text { the opinion of ...? }\end{array}$ & & & \multicolumn{2}{|l|}{$D=6$} & \\
\hline $\begin{array}{l}\text { Descriptive norms } \\
\text { towards the HPV } \\
\text { vaccination }\end{array}$ & $\begin{array}{l}\text { How many parents/girls do you know who } \\
\text { will decide to let their daughter/themselves } \\
\text { be vaccinated against HPV if they receive } \\
\text { the invitation? }\end{array}$ & $\begin{array}{l}1=\text { none of the } \\
\text { parents/girls I know, } \\
\text { to } 7=\text { all the } \\
\text { parents/girls I know }\end{array}$ & $\mathrm{n} / \mathrm{a}$ & 1 & $\mathrm{n} / \mathrm{a}$ & [31] \\
\hline \multirow{9}{*}{$\begin{array}{l}\text { Self-efficacy } \\
\text { expectations towards } \\
\text { the HPV vaccination }\end{array}$} & $\begin{array}{l}\text { To what extent would you succeed in } \\
\text { dealing with the following situations: }\end{array}$ & \multirow{9}{*}{$\begin{array}{l}-3=1 \text { would } \\
\text { certainly not } \\
\text { succeed to } 3=1 \\
\text { would certainly } \\
\text { succeed }\end{array}$} & \multirow{9}{*}{$\begin{array}{l}-18=\mid \text { would } \\
\text { certainly not } \\
\text { succeed to } 18=1 \\
\text { would certainly } \\
\text { succeed }\end{array}$} & \multirow[t]{9}{*}{6} & \multirow{9}{*}{$\begin{array}{l}M=.82 \\
D=.66\end{array}$} & \\
\hline & $\begin{array}{l}\text { - Finding reliable information about the } \\
\text { HPV vaccination; }\end{array}$ & & & & & \\
\hline & $\begin{array}{l}\text { - Understanding information about the } \\
\text { HPV vaccination; }\end{array}$ & & & & & \\
\hline & $\begin{array}{l}\text { - Making a different decision about the } \\
\text { HPV vaccination of my daughter/myself than } \\
\text { most parents/girls among my acquaintances; }\end{array}$ & & & & & \\
\hline & $\begin{array}{l}\text { - Having a good talk with my daughter } \\
\text { about the HPV vaccination }(\mathrm{M}) \text {; }\end{array}$ & & & & & \\
\hline & $\begin{array}{l}\text { - Having a good talk with my partner } \\
\text { about the HPV vaccination (M); }\end{array}$ & & & & & \\
\hline & $\begin{array}{l}\text { - Having a good talk with my father } \\
\text { about the HPV vaccination (D); }\end{array}$ & & & & & \\
\hline & $\begin{array}{l}\text { - Having a good talk with my mother } \\
\text { about the HPV vaccination (D); }\end{array}$ & & & & & \\
\hline & $\begin{array}{l}\text { - Having a good talk with my general } \\
\text { practitioner about the HPV vaccination. }\end{array}$ & & & & & \\
\hline \multirow[t]{4}{*}{$\begin{array}{l}\text { HPV vaccination } \\
\text { information processing }\end{array}$} & $\begin{array}{l}\text { Before I finally decided about my (daughter's) } \\
\text { vaccination, I... }\end{array}$ & & \multirow{4}{*}{$\begin{array}{l}-6=\text { completely } \\
\text { disagree to } 6= \\
\text { completely agree }\end{array}$} & \multirow[t]{4}{*}{2} & $M=.84$ & \multirow[t]{4}{*}{ [31] } \\
\hline & $\begin{array}{l}\text { - gathered a lot of information about the } \\
\text { HPV vaccine }\end{array}$ & & & & 15 & \\
\hline & - thoroughly considered the HPV vaccination & \multirow{2}{*}{$\begin{array}{l}-3=\text { completely } \\
\text { disagree to } 3= \\
\text { completely agree }\end{array}$} & & & & \\
\hline & $\begin{array}{l}\text { Participants rated their agreement on } \\
\text { both items separately }\end{array}$ & & & & & \\
\hline \multirow{5}{*}{$\begin{array}{l}\text { Habit strength towards } \\
\text { the HPV vaccination }\end{array}$} & Letting my daughter receive the HPV & \multirow{5}{*}{$\begin{array}{l}-3=\text { completely } \\
\text { disagree to } 3= \\
\text { completely agree }\end{array}$} & \multirow{5}{*}{$\begin{array}{l}-6=\text { completely } \\
\text { disagree to } 6= \\
\text { completely agree }\end{array}$} & \multirow[t]{5}{*}{2} & $M=.78$ & \multirow[t]{5}{*}{ [35] } \\
\hline & $\begin{array}{l}\text { vaccination/Recelving the HPV vaccination } \\
\text { is something I do... }\end{array}$ & & & & $\mathrm{D}=.65$ & \\
\hline & - automatically & & & & & \\
\hline & - without thinking & & & & & \\
\hline & $\begin{array}{l}\text { Participants rated their agreement on } \\
\text { both items separately }\end{array}$ & & & & & \\
\hline
\end{tabular}




\section{Table 1 Overview of social-psychological scale measures' ${ }^{1}$ (Continued)}

\begin{tabular}{|c|c|c|c|c|c|c|}
\hline $\begin{array}{l}\text { Decisional conflict } \\
\text { about the HPV } \\
\text { vaccination - value } \\
\text { clarity }\end{array}$ & $\begin{array}{l}\text { As regards the HPV vaccination... } \\
\text { - I was clear about which benefits were } \\
\text { most important to me; } \\
\text { - I was clear about which risks were } \\
\text { most important to me; } \\
\text { - I was clear about which was more } \\
\text { important to me, the benefits or the risks. }\end{array}$ & $\begin{array}{l}-3=\text { completely } \\
\text { disagree to } 3= \\
\text { completely agree }\end{array}$ & $\begin{array}{l}-9=\text { completely } \\
\text { disagree to } 9= \\
\text { completely agree }\end{array}$ & 3 & $\begin{array}{l}M=.89 \\
D=.85\end{array}$ & [36] \\
\hline $\begin{array}{l}\text { Decisional conflict } \\
\text { about the HPV } \\
\text { vaccination - certainty }\end{array}$ & $\begin{array}{l}\text { As regards the HPV vaccination... } \\
\text { - I felt sure about what to choose; } \\
\text { - the decision was relatively easy to make; } \\
\text { - I was clear about the best choice for } \\
\text { me/my daughter. }\end{array}$ & $\begin{array}{l}-3=\text { completely } \\
\text { disagree to } 3= \\
\text { completely agree }\end{array}$ & $\begin{array}{l}-9=\text { completely } \\
\text { disagree to } 9= \\
\text { completely agree }\end{array}$ & 3 & $\begin{array}{l}M=.89 \\
D=.87\end{array}$ & [36] \\
\hline $\begin{array}{l}\text { Opinion about } \\
\text { alternative medicine }\end{array}$ & $\begin{array}{l}\text { In what way do you agree with the view of... } \\
\text { - anthroposophy } \\
\text { - homeopathy } \\
\text { - other alternative medicine }\end{array}$ & $\begin{array}{l}-3=\text { completely } \\
\text { disagree to } 3= \\
\text { completely agree }\end{array}$ & $\begin{array}{l}-9=\text { completely } \\
\text { disagree to } 9= \\
\text { completely agree }\end{array}$ & 3 & $\begin{array}{l}M=.81 \\
D=.76\end{array}$ & \\
\hline $\begin{array}{l}\text { Past cancer } \\
\text { experience }^{d}\end{array}$ & $\begin{array}{l}\text { Have you/has your mother had experience } \\
\text { with... } \\
\text { Do you know someone from your } \\
\text { close environment who has/has had... } \\
\text { - cervical cancer } \\
\text { - other cancers } \\
\text { - abnormal pap smear }\end{array}$ & $\begin{array}{l}1=\text { no, } 2 \text { =yes, } \\
3=1 \text { do not want to } \\
\text { answer this question }\end{array}$ & $\mathrm{n} / \mathrm{a}$ & 6 & $\mathrm{n} / \mathrm{a}$ & {$[19,27]$} \\
\hline
\end{tabular}

Notes $\mathrm{M}=$ Mother; $\mathrm{D}=$ Daughter; $\mathrm{n} / \mathrm{a}$ = not applicable; 1 Scores on scaled item that showed sufficient internal consistency were summed into one scale; Mothers received questions about the HPV vaccination of their daughter, whereas daughters answered questions about the HPV vaccination of themselves; a) Knowledge is not a scale because the answer on one item does not predict the answer on the other items; the items were summed up to present a sum score of knowledge; b) The difference between the rated effectiveness of the HPV vaccination and the most effective alternative represented the relative effectiveness score ( $-9=$ HPV vaccination least effective to $9=$ HPV vaccination most effective); c) The subjective norms score was first computed by multiplying normative beliefs and motivation to comply for each social referent, and then by summing up the multiplications of the social referents; $d$ ) Past cancer experience is not a scale because the answer on one item does not predict the answer on the other items.

from the study population. The Theory of Planned Behavior [28], Social Cognitive Theory [29] and the Health Belief Model [30] formed the theoretical framework of this study. Mothers received questions about the HPV vaccination of their daughter, whereas daughters answered questions about the HPV vaccination of themselves. The questionnaire was pretested on a small sample from the study population, and subsequently revised. The revised questionnaire is described below.

\section{Vaccination intention}

Because social-psychological factors were measured at present and vaccination intention refers to future behavior, vaccination intention rather than past vaccination behavior was used as the criterion variable for examining the relationship between social-psychological factors and the $\mathrm{HPV}$ vaccination decision. Intention is a powerful predictor of infrequently performed behavior, such as obtaining a vaccination [37]. Vaccination intention was assessed by asking "If you had to make the HPV vaccination decision again, would you vaccinate your daughter/yourself against HPV?" ( $-3=$ certainly not, to $3=$ certainly yes) [31]

\section{Vaccination uptake}

Vaccination uptake was assessed by a dichotomous variable representing complete vaccination $($ no $=$ received less than three HPV injections; yes = received all three HPV injections). For participants recruited via Praeventis, HPV vaccination uptake information was available via the Praeventis vaccine register (i.e., number of HPV injections) as well as the survey (i.e., "Has your daughter received/Did you receive all three HPV injections?" (yes/no)). The percentage of agreement between objective and selfreported vaccination uptake for mothers and daughters from the Praeventis sample was determined by comparing the association between the Praeventis registry information with responses in the questionnaire. For participants recruited by the online panel, HPV vaccination uptake was available only via the survey ("How many HPV injections did your daughter/you receive?" (0 to 3 injections)).

\section{Social-psychological factors}

Social-psychological factors included knowledge, risk perception, attitude, outcome expectations, anticipated regret, beliefs, perceived relative effectiveness of the 
HPV vaccination, ambivalence, confidence in responsible authorities, subjective norms, descriptive norms, selfefficacy expectations, information processing, habit, decisional conflict (certainty, and value clarity), opinions about alternative medicine and past cancer experience (see Table 1 for an overview of the measures, sample items and the Cronbach's alpha). Scores on items that, taken as a group, had meaningful content coverage [38] and showed sufficient internal consistency (Cronbach's alpha $>0.60$ in at least one of the two samples) were summed into one scale. With regard to risk perception (i.e., perceived susceptibility and perceived severity), perceived severity was not measured because low variability was expected and a recent review showed no association with vaccine intention [12].

\section{Socio-demographic factors}

Socio-demographic factors were included to explore the need for segmentation of target groups in future educational interventions. The study accounted for age, gender, educational level, country of birth and religion.

Level of education was measured by asking mothers about the highest level of education that they had completed and by asking daughters about their own education and the highest level of education both their parents had completed (the parent with the highest completed educational level was used to rank the educational level of the parents). Highest completed educational level for adults was classified as low (less than secondary or vocational education), intermediate (secondary through pre-university education) or high (professional or university education). For the daughters, attained educational level was classified as intermediate (senior general secondary education or pre-university education) or low (other).

Country of birth was also assessed for mothers and daughters. The variables were classified into four categories which represent the largest ethnic groups in the Netherlands and matched our recruitment strategy: Netherlands, Surinam/Antilles/Aruba, Turkey/Morocco and other countries.

Religion was measured by asking participants about their religious convictions (Protestant, Roman Catholic, Muslim, Jewish, Buddhist, Hindu, other or no religion). Because a small minority of participants had another religion than Roman Catholic or Protestant, these participants were classified as "Roman Catholic" and people with "no religion" were put in the category "no religion". This information was further dichotomized into "Protestant" or "not Protestant" because an ANOVA revealed that Protestant participants had a significantly lower vaccine intention than Roman Catholics or people with no religion. Finally, we asked participants if the parents had differences in opinion about the acceptability of the HPV vaccine.

\section{Data analyses}

In all analyses, education level was treated as nominal, instead of ordinal, because we did not assume a monotonic increasing relationship of education level with the outcome variable "HPV-vaccination intention". The association between objective and self-reported vaccination uptake (i.e., received all three HPV injections versus received less than three HPV injections) for mothers and daughters was determined by chi-square tests. Differences between participants recruited from Praeventis and the online panel were examined by t-tests or chi-square tests with Statistical Package for Social Sciences (SPSS) 17.0. A two-sided alpha of .05 was used as the criterion for significance.

HPV vaccination intention was used as the criterion variable for examining the relationship between socialpsychological factors and the HPV vaccination decision, as it is consistent with behavioral theories (e.g., Theory of Planned Behavior) that explain future behavior via intention, by social-psychological determinants measured at present. We first examined the univariate relationship between social-psychological factors and vaccination intention with simple regression analysis. Because of the large amount of univariate tests, we used a two-sided alpha of .01 as the criterion for significance. Secondly, we conducted a backward linear regression analysis to examine which social-psychological factors were most dominantly associated with vaccination intention. Only significant factors from the univariate tests were included in the regression analyses as predictors in a fourth step, after correcting for HPV vaccination uptake in the first step, sample in the second step and socio-demographic variables in a third step. HPV vaccination uptake was included in the regression analysis as a first step because past behavior best predicts future behavior [28]. A two-sided $p \geq .01$ was used as the criterion for removal of a predictor in the backwards selection procedure. HPV vaccination uptake, sample, socio-demographic and social-psychological factors were included in the model by the forced entry method to determine their unique explained variance on vaccination intention.

To select the most important factors, the backward method was used to exclude non-significant variables (two-sided $p \geq .01$ ) from the model, except for HPV vaccination uptake, sample and socio-demographic variables for which differences were found between the two samples. Because we wanted to adjust for the latter variables in the final model, we applied a manually backward selection, instead of an automatic procedure. There was no indication of multicollinearity between variables in the regression model (variance inflation factor values $<10$ ). To further shape future recommendations, Pearson's correlation coefficients were calculated for the relationship between vaccination intention and individual study 
measure items that were significantly related to vaccination intention according to the multiple regression model.

The univariate and multivariate tests were first performed on a random sample of $75 \%$ of the participants. Data from the other (25\%) participants were used to check for stability and generalizability. The stability check examined which predictors from the final regression model among the $75 \%$ sample remained significant in the $25 \%$ sample; these were expected to be stable predictors. The generalizability check examined the predictive value of the final regression models for the vaccination intention of the population. This check was conducted to account for overestimation of the percentage of explained variance which mostly occurs in a regression analysis. The goodness-of-fit of the final regression model for the $75 \%$ sample was estimated for the $25 \%$ sample by keeping the estimated parameters (Betas) of the regression model for the $75 \%$ sample. This analysis was performed in $R$ [39]. Subsequently, the percentage of explained variance was compared between the two samples, with large differences indicating a large amount of overfitting [40].

\section{Results \\ Sample \\ Sample description}

In total, we analyzed data from 952 mothers and 642 daughters. No data were available from participants who did not respond to the invitation. The sample description is depicted in Table 2.

\section{Socio-demographic factors}

The mean age of the mothers and daughters was 43 years $(\mathrm{SD}=4.6)$ and 13 years $(\mathrm{SD}=0.5)$, respectively. Most of the mothers (88\%) and daughters (75\%) were born in the Netherlands, and $24 \%$ and $18 \%$ were Protestant, respectively. One quarter of the mothers $(26 \%)$ had a low educational level. More than half of the girls (58\%) attained a low educational level. The sample appeared to represent the general population in the Netherlands with regard to educational level [41], country of birth [42] and religion [43]. A small percentage (5\%) of mothers who had a partner $(n=880)$ indicated that they differed in opinion from their partner about the HPV vaccination. Eight percent of the daughters who had two parents $(n=595)$ indicated that their parents differed in opinion about the $\mathrm{HPV}$ vaccination.

\section{Vaccination intention}

Less than half of the mothers (45\%) and daughters (39\%) indicated that they would like or certainly like to receive the HPV vaccination if they were to decide in the future (Table 2). Among the mother-daughter pairs $(n=497)$, the vaccination intention of mothers strongly correlated with that of daughters $(r=.77 ; p<.001)$.

\section{Vaccination uptake}

Almost half of the mothers (45\%) indicated that their daughter received all three HPV injections in 2009, and $51 \%$ of the daughters indicated that they had received them. The association between objective and selfreported data on the number of received HPV injections ("has not received all three injections" versus "has received all three injections") in the Praeventis sample was high (mothers: $\mathrm{n}=441 ; \chi^{2}=290.56 ; \mathrm{p}<.001$; daughters: $\left.\mathrm{n}=399 ; \chi^{2}=325.02 ; \mathrm{p}<.001\right)$, and the percentage of agreement between both outcome variables appeared very large (91\% for mothers and 94\% for daughters). The correlation between HPV vaccination uptake and future vaccination intention was also significant for mothers $(r=.69 ; p<.001)$ and daughters $(r=.62 ; p<.001)$.

\section{Differences between participants recruited via Praeventis and the online panel}

Compared to mothers recruited via the online panel, those recruited via Praeventis were older (online panel 43.0 versus Praeventis 43.8 years of age; $\mathrm{t}=2.69, p=.007$, Table 2) and had completed a higher level of education (24\% versus $\left.37 \% ; \chi^{2}=17.73, p<.001\right)$, fewer mothers were born in the Netherlands (97\% versus $77 \% ; \chi^{2}=94.23$, $p<.001)$ and fewer mothers were Protestant (29\% versus $\left.18 \% ; \chi^{2}=13.43, p<.001\right)$. Among mothers, there were no differences between the samples with regard to HPV vaccination intention $(p=.95)$ and vaccination uptake $(p=.68)$.

Compared to daughters recruited via the online panel, those recruited via Praeventis were more likely to have parents with a lower completed level of education $(17 \%$ versus $26 \% ; \chi^{2}=17.14, p<.001$ ), were less likely to attain a lower educational level themselves (84\% versus $\left.43 \% ; X^{2}=103.93, p<.001\right)$, were less likely to have a mother who was born in the Netherlands (96\% versus $\left.63 \% ; X^{2}=90.66, p<.001\right)$, were less likely to have been born in the Netherlands themselves (98\% versus 90\%; $\left.\chi^{2}=17.97, p<.001\right)$ and were less likely to be Protestant ( $22 \%$ versus $\left.15 \% ; \chi^{2}=4.94, p=.03\right)$. Among daughters, there were no differences between the samples with regard to age $(p=.73)$, HPV vaccination intention $(p=.28)$ and vaccination uptake $(p=.36)$.

\section{Relationship between determinants and the HPV vaccination intention \\ Univariate tests}

According to the univariate regression analyses, the following factors significantly contributed to the mothers' (Table 3) and daughters' (Table 4) HPV vaccination intention: HPV vaccination uptake, religion, risk perception without having received the HPV vaccination, attitude, positive and negative outcome expectations, anticipated 
Table 2 Sample description (percentage or mean \pm standard deviation) ${ }^{1}$

\begin{tabular}{|c|c|c|c|c|c|c|}
\hline \multirow[t]{2}{*}{ Variables } & \multicolumn{3}{|l|}{ Mothers } & \multicolumn{3}{|l|}{ Daughters } \\
\hline & Praeventis $(n=441)$ & Panel $(n=511)$ & Total $(n=952)$ & Praeventis $(n=399)$ & Panel $(n=243)$ & Total $(n=642)$ \\
\hline Age & $43.81 \pm 4.74$ & $43.01 \pm 4.48$ & $43.38 \pm 4.62^{*}$ & $13.52 \pm 0.51$ & $13.50 \pm 0.51$ & $13.51 \pm 0.51$ \\
\hline Educational level mother & $\mathrm{N}_{\text {missing }}=2$ & & $\mathrm{~N}_{\text {missing }}=2^{*}$ & - & - & - \\
\hline Low & $24 \%$ & $27 \%$ & $26 \%$ & & & \\
\hline Intermediate & $39 \%$ & $49 \%$ & $44 \%$ & & & \\
\hline High & $37 \%$ & $24 \%$ & $30 \%$ & & & \\
\hline Educational level parents & - & - & - & $\mathrm{N}_{\text {missing }}=19$ & $\mathrm{~N}_{\text {missing }}=19$ & $\mathrm{~N}_{\text {missing }}=38^{*}$ \\
\hline Low & & & & $26 \%$ & $17 \%$ & $22 \%$ \\
\hline Intermediate & & & & $34 \%$ & $26 \%$ & $31 \%$ \\
\hline High & & & & $40 \%$ & $57 \%$ & $46 \%$ \\
\hline Educational level daughter & - & - & - & & $n=238$ & $n=637^{*}$ \\
\hline Low & & & & $43 \%$ & $84 \%$ & $58 \%$ \\
\hline Intermediate & & & & $57 \%$ & $16 \%$ & $42 \%$ \\
\hline Country of birth mother & $\mathrm{N}_{\text {missing }}=1$ & $\mathrm{~N}_{\text {missing }}=3$ & $\mathrm{~N}_{\text {missing }}=4^{*}$ & $\mathrm{~N}_{\text {missing }}=10$ & $\mathrm{~N}_{\text {missing }}=20$ & $\mathrm{~N}_{\text {missing }}=30^{*}$ \\
\hline The Netherlands & $77 \%$ & $97 \%$ & $88 \%$ & $63 \%$ & $96 \%$ & $75 \%$ \\
\hline Surinam/Antilles & $8 \%$ & $1 \%$ & $4 \%$ & $11 \%$ & $1 \%$ & $7 \%$ \\
\hline Turkey/Morocco & $10 \%$ & $0 \%$ & $5 \%$ & $21 \%$ & $0 \%$ & $13 \%$ \\
\hline Other & $5 \%$ & $2 \%$ & $3 \%$ & $5 \%$ & $3 \%$ & $4 \%$ \\
\hline Country of birth daughter & - & - & - & & & * \\
\hline The Netherlands & & & & $90 \%$ & $98 \%$ & $93 \%$ \\
\hline Surinam/Antilles & & & & $3 \%$ & $0 \%$ & $2 \%$ \\
\hline Turkey/Morocco & & & & $4 \%$ & $0 \%$ & $2 \%$ \\
\hline Other & & & & $3 \%$ & $2 \%$ & $3 \%$ \\
\hline Religion & $N_{\text {missing }}=2$ & $\mathrm{~N}_{\text {missing }}=1$ & $\mathrm{~N}_{\text {missing }}=3^{*}$ & & & * \\
\hline Protestant & $18 \%$ & $29 \%$ & $24 \%$ & $15 \%$ & $22 \%$ & $18 \%$ \\
\hline Number of HPV injections ${ }^{2}$ & $1.42 \pm 1.45$ & $1.59 \pm 1.42$ & $1.51 \pm 1.44$ & $1.47 \pm 1.46$ & $1.72 \pm 1.44$ & $1.56 \pm 1.46$ \\
\hline None & $50 \%$ & $43 \%$ & $46 \%$ & $49 \%$ & $40 \%$ & $46 \%$ \\
\hline One & $1 \%$ & $1 \%$ & $1 \%$ & $1 \%$ & $1 \%$ & $1 \%$ \\
\hline Two & $6 \%$ & $10 \%$ & $8 \%$ & $5 \%$ & $6 \%$ & $5 \%$ \\
\hline Three & $43 \%$ & $46 \%$ & $45 \%$ & $45 \%$ & $53 \%$ & $48 \%$ \\
\hline $\begin{array}{l}\text { Three HPV injections received } \\
\text { (self-reported) }\end{array}$ & $45 \%$ & $46 \%$ & $45 \%$ & $49 \%$ & $53 \%$ & $51 \%$ \\
\hline HPV vaccination intention & $0.57 \pm 2.07$ & $0.57 \pm 2.20$ & $0.57 \pm 2.14$ & $0.43 \pm 1.98$ & $0.61 \pm 2.03$ & $0.50 \pm 2.00$ \\
\hline Certainly not & $12 \%$ & $14 \%$ & $13 \%$ & $11 \%$ & $10 \%$ & $11 \%$ \\
\hline Not & $8 \%$ & $12 \%$ & $10 \%$ & $9 \%$ & $10 \%$ & $9 \%$ \\
\hline Probably not & $12 \%$ & $9 \%$ & $11 \%$ & $13 \%$ & $11 \%$ & $12 \%$ \\
\hline Probably not/yes & $11 \%$ & $7 \%$ & $9 \%$ & $15 \%$ & $14 \%$ & $15 \%$ \\
\hline Probably yes & $14 \%$ & $10 \%$ & $12 \%$ & $16 \%$ & $12 \%$ & $14 \%$ \\
\hline Yes & $19 \%$ & $22 \%$ & $20 \%$ & $17 \%$ & $18 \%$ & $17 \%$ \\
\hline Certainly yes & $24 \%$ & $26 \%$ & $25 \%$ & $20 \%$ & $25 \%$ & $22 \%$ \\
\hline
\end{tabular}

Notes 1) In case of missing values, the number of missing values (Nmissing) were presented; Mothers received questions about the HPV vaccination of their daughter, whereas daughters answered questions about the HPV vaccination of themselves; 2) These number represents daughters and are obtained from the vaccine registration for participants recruited via Praeventis, and are self-reported for participants recruited via an online panel; *Significant difference between Praeventis and the panel $(p<.05)$. 
regret with and without having received the HPV vaccination, beliefs, relative effectiveness of the HPV vaccination, confidence in responsible authorities, subjective norms, descriptive norms, information processing and habit strength. Among mothers, significance was also found for ambivalence, decisional conflict (certainty) and opinion about alternative medicine; among daughters, significance was also found for self-efficacy and decisional conflict (values clarity).

\section{Multivariate tests}

Tables 3 (mothers) and 4 (daughters) present factors that significantly contributed to the HPV vaccination intention according to the multivariate regression analyses.

\section{Mothers}

The unique contribution of HPV vaccination uptake (first step) to the explained variance of vaccination intention was large and significant $\left(\mathrm{R}^{2}=.47, p<.001\right)$. In addition, the samples (second step) did not significantly contribute to the explained variance of vaccination intention $\left(\Delta \mathrm{R}^{2}=.00 ; p=.83\right)$. The additional contribution of socio-demographic variables (third step) to the explained variance of vaccination intention was small but significant $\left(\Delta \mathrm{R}^{2}=.01, p=.007\right)$ for country of birth. The multivariate relationship between country of birth and intention was not found by the univariate test, which was most likely caused by the small percentage of mothers born in Turkey or Morocco (4\%). The social-psychological determinants (fourth step) largely and significantly contributed to the explained variance of vaccination intention $\left(\Delta R^{2}=.35\right.$; $p<.001)$ after correcting for HPV vaccination uptake, sample and socio-demographic variables: attitude, anticipated regret when accepting or refraining from vaccination, beliefs, subjective norms, habit strength and decisional conflict (certainty). The relationship between decisional conflict and intention has to be interpreted with caution, because univariate analyses showed the opposite relationship, which indicates a possible suppressor-effect. This suppressoreffect was probably caused by the high correlation between decisional conflict and habit $(r=.49 ; p<.001)$.

\section{Daughters}

The unique contribution of HPV vaccination uptake (first step) to the explained variance of vaccination intention was large and significant $\left(\mathrm{R}^{2}=.36, p<.001\right)$. The additional contribution of sample (second step) and socio-demographic variables (third step) to the explained variance of vaccination intention was not significant $\left(\Delta \mathrm{R}^{2}=.00, p=.69\right.$; and $\Delta \mathrm{R}^{2}=.02, p=.17$, respectively), whereas the additional contribution of social-psychological variables (fourth step) was large and significant $\left(\Delta \mathrm{R}^{2}=.34 ; p<.001\right)$. Attitude, beliefs, subjective norms and habit strength and risk perception (perceived susceptibility of getting cervical cancer without having received the HPV vaccination) significantly and uniquely contributed to the explanation of HPV vaccination intentions.

\section{Stability}

The stability of these models was tested on $25 \%$ of the total sample of mothers $(n=220)$ and daughters $(n=160)$. Results have to be interpreted with caution for country of birth because of the small percentage of participants born outside the Netherlands (13\% of mothers and $5 \%$ of daughters). The outcomes of these stability tests are also presented in Tables 3 (mothers) and 4 (daughters).

\section{Mothers}

Country of birth and anticipated regret no longer significantly contributed to the prediction of HPV vaccination intention. Attitude, beliefs, subjective norms, habit strength and decisional conflict (certainty) appeared to be stable factors since they contributed to the explained variance in both the $25 \%$ and $75 \%$ samples.

\section{Daughters}

Beliefs, habit strength and risk perception no longer significantly contributed to the explained variance of HPV vaccination intention. Anticipated regret when refraining from vaccination significantly and positively contributed to HPV vaccination intention for the $25 \%$ sample, though it did not for the $75 \%$ sample. Attitude and subjective norms appeared stable since they significantly entered the equation in both samples.

\section{Generalizability}

The generalizability of determinants of HPV vaccination intention was explored by replicating the final regression model found for the $75 \%$ samples in the remaining $25 \%$ samples. The explained variance of the final models remained high for the $25 \%$ samples $\left(\mathrm{R}^{2}=.80\right.$ for mothers, $R^{2}=.72$ for daughters). This means that the final models found for the $75 \%$ samples appeared to predict to a large extent the vaccination intention of the mothers and daughters from the total population.

\section{Influential elements of the HPV vaccination intention determinants}

More detailed insight into the most relevant determinants might be helpful for defining concrete objectives for designing interventions to promote HPV vaccination uptake. These analyses focused on the relative influence of individual items of the most relevant determinants from the final regression models (i.e., beliefs, subjective norms and habit for both mothers and daughters, and decisional conflict for mothers). Analyses for attitude were not conducted since the items on this scale were considered 
Table 3 Relationship of socio-demographic variables and social-psychological factors with the mothers' HPV vaccination intention

\begin{tabular}{|c|c|c|c|c|c|c|}
\hline \multirow[t]{2}{*}{ Variables } & \multicolumn{2}{|c|}{$\begin{array}{l}\text { Univariate simple regression } \\
\text { analysis among } 75 \% \text { of the } \\
\text { mothers }(n=732)\end{array}$} & \multicolumn{2}{|c|}{$\begin{array}{l}\text { Multivariate backward } \\
\text { regression analysis among } \\
75 \% \text { of the mothers }(n=727)\end{array}$} & \multicolumn{2}{|c|}{$\begin{array}{l}\text { Multivariate backward } \\
\text { regression analysis among } \\
25 \% \text { of the mothers }(n=219)\end{array}$} \\
\hline & $\begin{array}{l}\text { Mean (standard } \\
\text { deviation) or } \\
\text { percentage }\end{array}$ & Association $^{1}$ & $\begin{array}{l}\text { Beta (standard } \\
\text { error) }\end{array}$ & $\begin{array}{l}\text { Standardized } \\
\text { Beta }\end{array}$ & $\begin{array}{l}\text { Beta (standard } \\
\text { error) }\end{array}$ & $\begin{array}{l}\text { Standardized } \\
\text { Beta }\end{array}$ \\
\hline HPV vaccination uptake & & $.48^{* *}$ & $0.48(0.10)$ & $.11^{* *}$ & $0.57(0.19)$ & $.13^{*}$ \\
\hline Has not received three HPV-injections (reference) & $54 \%$ & & & & & \\
\hline Has received three HPV-injections & $46 \%$ & & & & & \\
\hline Sample & & .00 & $-0.01(0.07)$ & 0.00 & $0.15(0.14)$ & .04 \\
\hline Praeventis (reference) & $47 \%$ & & & & & \\
\hline Online panel & $53 \%$ & & & & & \\
\hline \multicolumn{7}{|l|}{ Socio-demographic variables } \\
\hline Age & $43.51(4.54)$ & .00 & $-0.01(0.01)$ & -.02 & $0.00(0.01)$ & .01 \\
\hline Highest completed level of education mother & & .00 & & & & \\
\hline Low (reference) & $25 \%$ & & & & & \\
\hline Intermediate & $45 \%$ & & $0.08(0.08)$ & .02 & $-0.02(0.17)$ & -.00 \\
\hline High & $30 \%$ & & $0.13(0.09)$ & .03 & $0.27(0.18)$ & .06 \\
\hline Country of birth mother & & .00 & & & & \\
\hline The Netherlands (reference) & $88 \%$ & & & & & \\
\hline Surinam/Antilles & $4 \%$ & & $-0.22(0.18)$ & -.02 & $0.42(0.32)$ & .04 \\
\hline Turkey/Morocco & $4 \%$ & & $-0.51(0.18)$ & $-.05^{*}$ & $0.18(0.32)$ & .02 \\
\hline Other & $3 \%$ & & $-0.30(0.18)$ & -.03 & $0.10(0.41)$ & .01 \\
\hline Protestant religion & & $.02^{* *}$ & & & & \\
\hline No (reference) & $77 \%$ & & & & & \\
\hline Yes & $23 \%$ & & $-0.08(0.08)$ & -.02 & $-0.05(0.15)$ & -.01 \\
\hline
\end{tabular}

Social psychological variables

Knowledge about the HPV vaccination

$4.82(2.42) \quad .00$

$-0.61(1.21) \quad .20^{* *}$

vaccination)

Risk perception (having received the HPV vaccination)

Attitude towards the HPV vaccination

Negative outcome expectations of the HPV vaccination

Positive outcome expectations of the HPV vaccination

Anticipated regret about rejecting the HPV vaccination

Anticipated regret about receiving the vaccination

Beliefs about the HPV vaccination

$$
-1.22(1.09)
$$$$
.01
$$

$2.78(6.93) \quad .76^{* *}$

$7.24(4.56) \quad .14^{* *}$

$-3.44(3.86) \quad .10^{* *}$

$3.27(1.44) \quad .46^{* *}$

$46^{* *}$

$0.20(0.03) \quad .13^{* *}$

$1.42(9.92)$

$.06^{* *}$

$-0.08(0.03)$

$-.05^{*}$

Relative effectiveness of the HPV vaccination

$-0.61(1.20)$

$.60^{* *}$

$0.03(0.01)$

$.14^{* *}$

$.54^{* *}$

Ambivalence towards the HPV vaccination

$0.36(5.30)$

$.01 *$ 
Table 3 Relationship of socio-demographic variables and social-psychological factors with the mothers' HPV vaccination intention (Continued)

\begin{tabular}{|c|c|c|c|c|c|c|}
\hline $\begin{array}{l}\text { Confidence in authorities involved in the } \\
\text { HPV vaccination }\end{array}$ & $1.60(3.49)$ & $.42^{* *}$ & & & & \\
\hline Subjective norms towards the HPV vaccination & $16.81(23.57)$ & $.67^{* *}$ & $0.02(0.00)$ & $.19^{* *}$ & $0.02(0.01)$ & $.20^{* *}$ \\
\hline Descriptive norms towards the HPV vaccination & $4.53(1.34)$ & $.15^{* *}$ & & & & \\
\hline $\begin{array}{l}\text { Self-efficacy expectations towards the } \\
\text { HPV vaccination }\end{array}$ & $11.87(4.66)$ & .01 & & & & \\
\hline HPV vaccination information processing & $3.79(2.40)$ & $.06^{* *}$ & & & & \\
\hline Habit strength towards the HPV vaccination & $-0.81(3.64)$ & $.41^{* *}$ & $0.07(0.02)$ & $.11^{* *}$ & $0.12(0.03)$ & $.19^{* *}$ \\
\hline $\begin{array}{l}\text { Decisional conflict about the HPV } \\
\text { vaccination - value clarity }\end{array}$ & $3.03(4.29)$ & .00 & & & & \\
\hline $\begin{array}{l}\text { Decisional conflict about the HPV } \\
\text { vaccination - certainty }\end{array}$ & $2.00(4.69)$ & $.02^{* *}$ & $-0.05(.01)$ & $-.10^{* *}$ & $-0.07(0.02)$ & $-.15^{* *}$ \\
\hline Opinion about alternative medicine & $-0.43(2.37)$ & $.02^{*}$ & & & & \\
\hline Past experience of the mother with cervical cancer & & .00 & & & & \\
\hline No (reference) & $98 \%$ & & & & & \\
\hline Yes & $2 \%$ & & & & & \\
\hline $\begin{array}{l}\text { Past experience of the mother with other } \\
\text { cancer forms }\end{array}$ & & .00 & & & & \\
\hline No (reference) & $97 \%$ & & & & & \\
\hline Yes & $3 \%$ & & & & & \\
\hline $\begin{array}{l}\text { Past experience of the mother with } \\
\text { abnormal pap smear }\end{array}$ & & .00 & & & & \\
\hline No (reference) & $87 \%$ & & & & & \\
\hline Yes & $13 \%$ & & & & & \\
\hline $\begin{array}{l}\text { Past experience of someone from the } \\
\text { close environment with cervical cancer }\end{array}$ & & .00 & & & & \\
\hline No (reference) & $67 \%$ & & & & & \\
\hline Yes & $33 \%$ & & & & & \\
\hline $\begin{array}{l}\text { Past experience of someone from the } \\
\text { close environment with other cancer forms }\end{array}$ & & .00 & & & & \\
\hline No (reference) & $10 \%$ & & & & & \\
\hline Yes & $90 \%$ & & & & & \\
\hline $\begin{array}{l}\text { Past experience of someone from the close } \\
\text { environment with abnormal pap smear }\end{array}$ & & 0.00 & & & & \\
\hline No (reference) & $50 \%$ & & & & & \\
\hline Yes & $50 \%$ & & & & & \\
\hline
\end{tabular}

Model fit for multivariate models

$\mathrm{R}^{2}$ of HPV vaccination uptake

$R^{2}$ change of HPV vaccination uptake

$F$ change of HPV vaccination uptake

$R^{2}$ of HPV vaccination uptake + sample

$\mathrm{R}^{2}$ change of HPV vaccination uptake + sample 


\section{Table 3 Relationship of socio-demographic variables and social-psychological factors with the mothers' HPV vaccination intention (Continued)}

\begin{tabular}{|c|c|c|}
\hline $\begin{array}{l}\text { F change of HPV vaccination uptake }+ \\
\text { sample }+ \text { socio-demographic variables }\end{array}$ & $2.82^{*}$ & 1.37 \\
\hline $\begin{array}{l}\mathrm{R}^{2} \text { of HPV vaccination uptake + sample }+ \text { socio- } \\
\text { demographic + social-psychological variables }\end{array}$ & .84 & .81 \\
\hline $\begin{array}{l}\mathrm{R}^{2} \text { change of HPV vaccination uptake }+ \text { sample }+ \\
\text { socio-demographic }+ \text { social-psychological variables }\end{array}$ & .35 & .31 \\
\hline $\begin{array}{l}\text { F change of HPV vaccination uptake + sample }+ \\
\text { socio-demographic }+ \text { social-psychological variables }\end{array}$ & $218.92^{* *}$ & $66.04^{* *}$ \\
\hline
\end{tabular}

too general in nature to have practical relevance in this respect.

\section{Beliefs}

The following beliefs significantly (all $p<.001$ unless mentioned) correlated with the HPV vaccination intention of both mothers and daughters (The scales differ for positive $(-3=$ completely disagree to $3=$ completely agree $)$ and negative $(-3=$ completely agree to $3=$ completely disagree) beliefs (see Table 1 for details). A higher score represents a more positive opinion about HPV vaccination): "If the government offers the vaccination, I assume it will be safe" ( $r$ Mother $(r \mathrm{M})=.65$ and $r$ Daughter $(r \mathrm{D})=.57)$; "The HPV vaccination was only introduced because the pharmaceutical industry will earn a lot of money from it" $(r \mathrm{M}=.60$ and $r \mathrm{D}=.40$ ); "Our government is showing responsibility for the health of the Dutch population by introducing the $\mathrm{HPV}$ vaccination" ( $r \mathrm{M}=.60$ and $\mathrm{D} r=.24)$; "There is too little known about whether the HPV vaccination effectively protects against cervical cancer" ( $r \mathrm{M}=.59$ and $r \mathrm{D}=.53)$; "There is too little known about the detrimental side effects of the HPV vaccination" $(r \mathrm{M}=.57$ and $r \mathrm{D}=.42)$; "My daughter is too young to receive the HPV vaccination" $(r \mathrm{M}=.57$ and $r \mathrm{D}=.40)$; and "My daughter does not need to get the HPV vaccination if she is already sexually active" $(r \mathrm{M}=.19 ; r \mathrm{D}=.48, p=.001)$. The belief that a daughter does not need the vaccination because she is not yet sexually active positively and significantly correlated with the mothers' HPV vaccination intentions $(r=.63)$, whereas this relationship was not significant among daughters $(r=.10 ; p=.03)$. The belief that it is inappropriate that the daughter has to pay for the HPV vaccination if she decides to get the vaccination at a higher age was positively and significantly related to the HPV vaccination intention of daughters $(r=.23)$, while it was not significantly related to the intention of mothers $(r=.05 ; p=.21)$.

\section{Subjective norms}

Mothers and daughters were significantly more likely to vaccinate against HPV when they expected a positive influence from their friends $(r \mathrm{M}=.58$ and $r \mathrm{D}=.39)$, general practitioners $(r \mathrm{M}=.52$ and $r \mathrm{D}=.42)$, physicians or nurses from the municipal health service $(r \mathrm{M}=.46$ and $r \mathrm{D}=.41)$ and the Ministry of Health $(r \mathrm{M}=.42$ and $r \mathrm{D}=.29$; all $p<.001)$. This also applied to mothers when they expected a positive influence from their partners $(r=.80)$, daughters $(r=.76)$ and parents $(r=.66)$, and to daughters when they expected a positive influence from their mothers $(r=.71)$ and fathers $(r=.62$; all $p<.001)$.

\section{Habit strength}

Mothers and daughters were more inclined to accept the $\mathrm{HPV}$ vaccination when they perceived it as automatic event $(r \mathrm{M}=.70$ and $r \mathrm{D}=.61)$, without much thinking $(r \mathrm{M}=.47$ and $r \mathrm{D}=.35$; all $p<.001)$.

\section{Decisional conflict (certainty)}

Decisional conflict (certainty) significantly contributed to the mothers' HPV vaccination intention. Mothers were more likely to let their daughter receive the HPV vaccination if they perceived the decision as relatively easy to make $(r=.22 ; p<.001)$. The item "As regards the HPV vaccination, I was clear about the best choice for my daughter" was borderline significant $(r=.09 ; p=.01)$; mothers seemed more likely to let their daughter receive the HPV vaccination if they agreed with this statement. The other item on this scale was not significantly associated with the mothers' HPV vaccination intentions: "As regards the HPV vaccination, I felt sure about what to choose" $(r=.04 ; p=.28)$.

\section{Discussion}

This paper presents empirically tested the socialpsychological determinants of the HPV vaccination intention among girls and their mothers who received an invitation for the first Dutch catch-up campaign in 2009. This is one of the first studies to examine these determinants among participants who had actually made the decision about the HPV vaccination in the preceding year. Our results into determinants of the HPV vaccination decision confirm results from previous 
Table 4 Relationship of socio-demographic variables and social-psychological factors with the daughters' HPV vaccination intention

\begin{tabular}{|c|c|c|c|c|c|c|}
\hline \multirow[t]{2}{*}{ Variables } & \multicolumn{2}{|c|}{$\begin{array}{l}\text { Univariate simple regression } \\
\text { analysis among } 75 \% \text { of the } \\
\text { daughters }(n=482)\end{array}$} & \multicolumn{2}{|c|}{$\begin{array}{l}\text { Multivariate backward } \\
\text { regression analysis among } \\
75 \% \text { of the daughters }(n=452)\end{array}$} & \multicolumn{2}{|c|}{$\begin{array}{l}\text { Multivariate backward } \\
\text { regression analysis among } \\
25 \% \text { of the daughters }(n=147)\end{array}$} \\
\hline & $\begin{array}{l}\text { Mean (standard } \\
\text { deviation) or } \\
\text { percentage }\end{array}$ & Association $^{1}$ & $\begin{array}{l}\text { Beta (standard } \\
\text { error) }\end{array}$ & $\begin{array}{l}\text { Standardized } \\
\text { Beta }\end{array}$ & $\begin{array}{l}\text { Beta (standard } \\
\text { error) }\end{array}$ & $\begin{array}{l}\text { Standardized } \\
\text { Beta }\end{array}$ \\
\hline HPV vaccination uptake & & $.35^{* *}$ & $0.36(0.14)$ & $.09^{*}$ & $0.92(0.25)$ & $.23 * *$ \\
\hline
\end{tabular}

Has not received three HPV-injections (reference)

Has received three HPV-injections

52

48

Sample

Praeventis (reference)

Online panel

Socio-demographic variables

Age

Educational level daughter

Low (reference)

Intermediate

Highest completed level of education of parents

Low (reference)

Intermediate

High

Country of birth mother

The Netherlands (reference)

Surinam/Antilles

Turkey/Morocco

Other

Country of birth daughter

The Netherlands (reference)

Surinam/Antilles

Turkey/Morocco

Other

Protestant religion

No (reference)

Yes

Social psychological variables

Knowledge about the HPV vaccination

Risk perception (having received no HPV vaccination)

Risk perception (having received the HPV vaccination)

Attitude towards the HPV vaccination

Negative outcome expectations of the HPV vaccination

64

36

$7 \%$

$4 \%$
.00

$0.15(0.13)$

.04

$0.11(0.23)$

.03

$13.51(0.51) \quad .00$

.00

$59 \%$

$41 \%$

.00

$22 \%$

$32 \%$

$46 \%$

$0.08(0.15)$

.02

$0.18(0.24)$

.04

$0.04(0.15)$

.01

$0.31(0.23)$

.08

.00

$74 \%$

$15 \%$

$0.05(0.24)$

.01

$0.08(0.41)$

.01

-0.09 (0.19)

$-.02$

$0.25(0.34)$

$-1.18(0.45)$

$-.13$

.00

$92 \%$

$3.59(2.41) \quad .00$
$2 \%$

$3 \%$

$3 \%$

$.02 *$

$82 \%$

$19 \%$

$-0.61(1.39) \quad .23^{* *}$

$0.19(0.04)$

$.13^{* *}$

$-1.49(1.22)$

.00

$2.43(6.02) \quad .62^{* *}$

$0.12(0.01) \quad .37^{* *}$

$.09 * *$

$\begin{array}{ll}-0.74(0.43) & -.05 \\ 0.21(0.33) & .02 \\ 0.35(0.33) & .03\end{array}$

$0.02(0.13)$

.00

$-0.15(0.23)$

$-.03$

5.66 (4.71) 
Table 4 Relationship of socio-demographic variables and social-psychological factors with the daughters' HPV vaccination intention (Continued)

\begin{tabular}{|c|c|c|c|c|c|c|}
\hline $\begin{array}{l}\text { Positive outcome expectations of the HPV } \\
\text { vaccination }\end{array}$ & $-1.02(4.17)$ & $.10^{* *}$ & & & & \\
\hline $\begin{array}{l}\text { Anticipated regret about rejecting the HPV } \\
\text { vaccination }\end{array}$ & $3.24(1.43)$ & $.27^{* *}$ & & & $0.24(0.08)$ & $.17^{*}$ \\
\hline $\begin{array}{l}\text { Anticipated regret about receiving the } \\
\text { vaccination }\end{array}$ & $3.11(1.52)$ & $.09^{* *}$ & & & & \\
\hline Beliefs about the HPV vaccination & $2.11(8.31)$ & $.47^{* *}$ & $0.05(0.01)$ & $.21^{* *}$ & & \\
\hline Relative effectiveness of the HPV vaccination & $-2.45(2.61)$ & $.36^{* *}$ & & & & \\
\hline $\begin{array}{l}\text { Ambivalence towards the HPV vaccination } \\
\text { decision }\end{array}$ & $-0.11(4.64)$ & .00 & & & & \\
\hline $\begin{array}{l}\text { Confidence in authorities involved in the } \\
\text { HPV vaccination }\end{array}$ & $1.46(3.49)$ & $.29^{* *}$ & & & & \\
\hline Subjective norms towards the HPV vaccination & $13.87(18.60)$ & $.46^{* *}$ & $0.02(0.00)$ & $.15^{* *}$ & $0.03(0.01)$ & $.23^{*}$ \\
\hline $\begin{array}{l}\text { Descriptive norms towards the HPV } \\
\text { vaccination }\end{array}$ & $4.51(1.42)$ & $.11^{* *}$ & & & & \\
\hline $\begin{array}{l}\text { Self-efficacy expectations towards the } \\
\text { HPV vaccination }\end{array}$ & $1.43(4.70)$ & $.06^{* *}$ & & & & \\
\hline HPV vaccination information processing & $1.00(3.16)$ & $.03 * *$ & & & & \\
\hline Habit strength towards the HPV vaccination & $-0.28(3.02)$ & $.32^{* *}$ & $0.08(0.02)$ & $.12^{* *}$ & & \\
\hline $\begin{array}{l}\text { Decisional conflict about the HPV } \\
\text { vaccination - value clarity }\end{array}$ & $1.92(3.99)$ & $.02^{*}$ & & & & \\
\hline $\begin{array}{l}\text { Decisional conflict about the HPV } \\
\text { vaccination - certainty }\end{array}$ & $2.06(4.12)$ & .01 & & & & \\
\hline Opinion about alternative medicine & $-0.28(1.65)$ & .00 & & & & \\
\hline $\begin{array}{l}\text { Past experience of the mother with } \\
\text { cervical cancer }\end{array}$ & & .00 & & & & \\
\hline No (reference) & $98 \%$ & & & & & \\
\hline Yes & $2 \%$ & & & & & \\
\hline
\end{tabular}

Past experience of the mother with other cancer forms

No (reference) 96\%

Yes

$4 \%$

Past experience of the mother with abnormal pap smear

No (reference)

$92 \%$

Yes

$8 \%$

Past experience of someone from the close environment with cervical cancer

$87 \%$

$13 \%$

Yes

Past experience of someone from the close environment with other cancer forms No (reference)

Yes

$78 \%$

Past experience of someone from the close environment with abnormal pap smear

No (reference)

$86 \%$

Yes

$14 \%$ 


\section{Table 4 Relationship of socio-demographic variables and social-psychological factors with the daughters' HPV vaccination intention (Continued)}

\begin{tabular}{|c|c|c|}
\hline \multicolumn{3}{|l|}{ Model fit for multivariate models } \\
\hline $\mathrm{R}^{2}$ of HPV vaccination uptake & .36 & .49 \\
\hline$R^{2}$ change of HPV vaccination uptake & .36 & .49 \\
\hline F change of HPV vaccination uptake & $257.28^{* *}$ & $137.34^{* *}$ \\
\hline $\mathrm{R}^{2}$ of HPV vaccination uptake + sample & .36 & .49 \\
\hline$R^{2}$ change of HPV vaccination uptake + sample & .00 & .00 \\
\hline F change of HPV vaccination uptake + sample & 0.16 & 0.58 \\
\hline $\begin{array}{l}\mathrm{R}^{2} \text { of HPV vaccination uptake }+ \text { sample }+ \\
\text { socio-demographic variables }\end{array}$ & .38 & .54 \\
\hline $\begin{array}{l}\mathrm{R}^{2} \text { change of HPV vaccination uptake }+ \\
\text { sample + socio-demographic variables }\end{array}$ & .02 & .05 \\
\hline $\begin{array}{l}\text { F change of HPV vaccination uptake }+ \\
\text { sample }+ \text { socio-demographic variables }\end{array}$ & 1.41 & 1.54 \\
\hline $\begin{array}{l}\mathrm{R}^{2} \text { of HPV vaccination uptake }+ \text { sample }+ \\
\text { socio-demographic }+ \text { social-psychological } \\
\text { variables }\end{array}$ & .73 & .77 \\
\hline $\begin{array}{l}\mathrm{R}^{2} \text { change of HPV vaccination uptake }+ \\
\text { sample }+ \text { socio-demographic }+ \\
\text { social-psychological variables }\end{array}$ & .34 & .24 \\
\hline $\begin{array}{l}\text { F change of HPV vaccination uptake }+ \\
\text { sample }+ \text { socio-demographic }+ \\
\text { social-psychological variables }\end{array}$ & $109.17^{* *}$ & $45.91^{* *}$ \\
\hline
\end{tabular}

research that was performed before or after implementation (i.e., when girls and parents did not have to make the decision in the immediate future). Another insight of this study is that we combined various predictors from socialpsychological research used in previous studies in one comprehensive set. As such, we were able to demonstrate which predictors of the set proved to be a sufficient, stable and generalizable combination. This is also one of the first studies that examined the contribution of these determinants to the explained variance of the HPV vaccination decision. This study revealed that HPV vaccination uptake made the largest contribution to the explained variance of HPV vaccination intention. We also found that social-psychological factors were far more important than socio-demographic factors in explaining the HPV vaccination intention. Moreover, social-psychological factors appeared to predict to a considerable extent the HPV vaccination intention of mothers and daughters from the total population.

HPV vaccination uptake made the largest contribution to the explained variance of HPV vaccination intention (47\% among mothers, $36 \%$ among daughters). It is a common finding that past behavior is the best predictor of future behavior [28]. Secondary analyses revealed that exclusion of HPV vaccination uptake from the regression model did not decrease the prediction of HPV vaccination intention (mothers: $\mathrm{R}^{2}=.83$ excluding and $\mathrm{R}^{2}=.84$ including HPV vaccination intake; daughters: $\mathrm{R}^{2}=.73$ including and excluding HPV vaccination intake). In addition, secondary analyses showed that socialpsychological variables explained more than two-thirds of the variance in HPV vaccination intention when HPV vaccination uptake was excluded from the model (mothers: $\Delta \mathrm{R}^{2}=.80$; daughters: $\Delta \mathrm{R}^{2}=.69$ ). These results indicate that our final regression model was sufficient and contained all important social-psychological determinants [28].

The contribution of social demographic variables to the explained variance of the HPV vaccination intention appeared small $(\leq 5 \%)$ and inconsistent. In contrast, the contribution of social-psychological determinants to the explained variance of the HPV vaccination intention was considerable (35\% among mothers, 34\% among daughters). This was an important finding, because the implications for future HPV vaccination communication are best found through these 'modifiable' social-psychological determinants of the HPV vaccination decision. Social-psychological factors that were not related to the HPV vaccination intention were, for example past cancer experiences and knowledge. With regard to past cancer experience, results of the present study confirm outcomes from a systematic review on HPV vaccination intention [12] and a study on other vaccinations [44]. These results reject the hypothesis that people are less willing to comply with national 
immunization programs because they are not as confronted with the seriousness of the target diseases as former generations, just because of the successes of these programs. In fact, almost all (>75\%) study participants knew someone from their close environment who has or has had cancer (Tables 3 and 4). The absence of a relationship between knowledge and HPV vaccination intentions also confirms the results found by others [12,26,44-46]. This may also be attributed to the fact that knowledge gaps hardly existed; the percentage of correct answers was high, especially among mothers $(\geq 70 \%)$.

Attitude, beliefs and subjective norms were the socialpsychological factors that appeared to be most strongly and consistently related to HPV vaccination intentions. Attitude played the most prominent role in the explanation of the HPV vaccination intention, confirming previous findings $[16,18,19,47]$. The most dominant attitude-based beliefs were beliefs about the safety and effectiveness of the HPV vaccine, sexual maturation and optimism (misplaced or not) about future sexual risk taking, economic profit for the pharmaceutical industry, and trust in the government's policies with respect to prevention of infectious diseases. Many relationships found in this study confirm others' findings, such as beliefs about the safety and effectiveness of the HPV vaccine $[12,47]$, sexual maturation and perceived future risk taking [12,47] and trust in the government's prevention policies $[19,21]$.

With regard to subjective norms, the influence of important others on HPV vaccination intention was most dominant for close family members (mother, father, and daughter). These results are similar to other studies about HPV vaccination [27] or the intention to take vaccinations in general [44]. Future communication strategies should therefore primarily be focused on these close family members. Aside from the expected social rewards, the mothers' parents, friends, the general practitioner, and the physician or nurse from the regional health service also played a role in the decision making process. The impact of the subjective norms of physicians on HPV vaccination decision making was also previously found $[12,19,20]$. Because there was a lot of public debate about the HPV vaccination among physicians before the onset of the first catch-up campaign [48], future communication strategies should also target physicians as important party to make them aware of their influence on HPV vaccination decision making by mothers and daughters.

Social-psychological factors that were also, but less consistently, related to HPV vaccination intention, were risk perception, anticipated regret, and habit strength. As for risk perception, daughters were more inclined to accept the vaccination if they felt a higher perceived susceptibility to cervical cancer without the HPV vaccination. This was also found by others $[12,16,17,49]$. Mothers were also more inclined to accept the HPV vaccination for their daughter when they anticipated more feelings of regret if their daughters received no vaccination and developed cervical cancer later in life. Mothers who anticipated more feelings of regret if their daughters contracted a serious illness because of the HPV vaccination had a lower intention to let their daughters get the HPV vaccination. Secondary analyses indicated that the respondents anticipated stronger feelings of regret towards illness without having received the vaccination than after having received the vaccination. The importance of anticipated regret confirms what was found by other studies on HPV vaccination decision making [50] and on the intention of child vaccinations in general [44].

With regard to habit, mothers had higher intentions to let their daughters receive the HPV vaccination if they perceived getting the vaccination as something they did automatically or without thinking. This is probably caused by past confidence in the NIP. However, people who perceive the HPV vaccination as something one does automatically, without much thinking, may be more susceptible to counterarguments compared to deliberate decision makers [44]. They should therefore be better prepared for possible confrontation with those counterarguments [44].

\section{Strengths}

One important strength of this study is the generalizability of the study results: the social-psychological factors appeared to predict to a large extent the vaccination intention of mothers and daughters from the total population. Another strength was that our final regression model contained all important social-psychological determinants [28]. Also, the total study sample was representative for the Dutch population with regard to educational level [41], country of birth [42] and religion [43]. This was a notable strength, because part of our sample was recruited via an online panel and the representativeness of online panels may be limited [51]. Another strength was that the HPV vaccination uptake among study participants corresponded to the national HPV vaccination coverage in 2009 [52]. In addition, self-reported vaccination uptake appeared to be a reliable measure for the objective vaccination uptake from the national vaccination register; there was a high percentage of agreement between them $(>90 \%$ of mothers and daughters). Our choice to use the mothers to represent the parents' HPV vaccination opinion appeared to be adequate, since almost all participants (>90\% of mothers and daughters) indicated that there was no difference in opinion between the parents.

\section{Limitations}

The present study had some limitations that are worth mentioning. First, it was based on a cross-sectional design, which makes it impossible to draw definite conclusions 
about causality of the associations found. Second, the response rate among subjects from the Praeventis sample was very low (7\%). A low response rate $(25 \%)$ was also found in another study which recruited parents through Praeventis to examine their attitude towards universal vaccination against hepatitis $B$ [53]. The low response rate in the present study could be explained by the use of online questionnaires, because using such questionnaires results in lower response rates than using other types of questionnaires $[54,55]$. In addition, the use of a written invitation to recruit participants could have caused the low response rate, because such an invitation result in lower response rates than an e-mail invitation in studies using online questionnaires [54]. Besides, participants recruited by Praeventis received no reward for their participation in the study, whereas participants from the online panel did. Although the reward was small, it can increase response rates in questionnaire research [56]. Also, the low response rate among participants from Praeventis compared to participants from the online panel could be explained by the differences in the nature between the samples. Participants from an online panel chose to be part of that panel and are therefore self-selected. This does not apply to participants from Praeventis. Finally, response rates are declining recently [57], probably due to oversurveying. The usefulness of information gained from a sample with such a low response rate is questionable. However, we have reason to believe that the results of this sample are useful, because the total study sample was representative for the Dutch population (see also "Strengths").

\section{Implications}

\section{Future research}

We recommend a longitudinal research approach in order to confirm the causality of the associations between socialpsychological factors and HPV vaccination behavior.

\section{Future communication strategies}

We recommend future communication addressing social-psychological variables that appear to be related to HPV vaccination (i.e. attitude, beliefs, subjective norms, habit, anticipated regret and perceived susceptibility). For example, future communication could address important beliefs about the safety of the vaccine, could reduce unrealistic optimism about the expected monogamy of the daughter and could emphasize the importance of receiving the HPV vaccination before daughters become sexually active. Furthermore, future communication strategies about the HPV vaccination should be targeted at daughters and their parents. Both parents appeared to play the most important role in mothers' and daughters' vaccination decision making. In addition, we recommend maintaining or improving confidence in authorities involved in the HPV vaccination, for example, by preventing conflict of interest with the pharmaceutical industry, or by communicating about safety as well as risks of the HPV vaccination. Finally, a tailored communication approach should be considered, because it has already been successfully applied to a variety of health-related behaviors, especially in targeting social-psychological variables also found in the present study $[58,59]$.

\section{Conclusions}

This is one of the first studies to examine determinants of the HPV vaccination intention among participants who had actually made the decision about the HPV vaccination in the preceding year. The study revealed that socialpsychological factors were far more important than socio-demographic factors in explaining HPV vaccination intention. Attitude, beliefs, subjective norms and habit strength were significantly associated with both the mothers' and the daughters' HPV vaccination intentions. Moreover, the generalizability of the study results was adequate. Future communication strategies targeting HPV vaccination uptake should address these determinants.

\section{Competing interests}

The authors declare that they have no competing interests.

\section{Authors' contribution}

HMVK and MF developed and executed the study, with TWGMP, WO, RACR and JVS advising on its development. ED advised on the conceptions of data collection and executed parts of the data analyses. HMVK and TWGMP significantly contributed to the writing of the manuscript, while WO, RACR, MF, JVS and ED were involved in revising it. All authors have seen and approved of the version to be published.

\section{Acknowledgements}

This study was funded by the Netherlands Organization for Health Research and Development (ZonMw, 50-50800-98-103).

\section{Author details}

${ }^{1}$ TNO (Netherlands Organization for Applied Scientific Research), Expertise Center Life Style, PO Box 2215, Leiden 2301 CE, the Netherlands.

${ }^{2}$ Department of Work and Social Psychology, Maastricht University, PO Box 616, Maastricht 6200 MD, the Netherlands. ${ }^{3}$ National Institute for Public Health and the Environment (RIVM), Center for Infectious Disease Control, PO Box 1, Bilthoven 3720 BA, the Netherlands. ${ }^{4}$ Leiden University Medical Center Center for Infectious Diseases, PO Box 9600, Leiden 2300 RC, the Netherlands.

Received: 15 December 2011 Accepted: 24 January 2013

Published: 6 February 2013

\section{References}

1. De Kok IMCM, Van Kranen HJ: Wat is het bereik? http://www. nationaalkompas.nl.

2. Gezondheidsraad: Vaccinatie tegen baarmoederhalskanker. Den Haag: Gezondheidsraad; 2008:154.

3. Schiffman M, Castle PE: Human papillomavirus: epidemiology and public health. Arch Pathol Lab Med 2003, 127(8):930-934.

4. Clifford G, Franceschi S, Diaz M, Munoz N, Villa LL: Chapter 3: HPV typedistribution in women with and without cervical neoplastic diseases. Vaccine 2006, 24(Suppl 3):26-34.

5. Smith JS, Lindsay L, Hoots B, Keys J, Franceschi S, Winer R, Clifford GM: Human papillomavirus type distribution in invasive cervical cancer and high-grade cervical lesions: a meta-analysis update. Int J Cancer 2007, 121(3):621-632.

6. Kimman TG, Boot HJ, Berbers GA, Vermeer-de Bondt PE, de Wit GA, de Melker HE: Developing a vaccination evaluation model to support 
evidence-based decision making on national immunization programs. Vaccine 2006, 24(22):4769-4778.

7. RIVM: Vaccinatiegraad Rijksvaccinatieprogramma Nederland. Verslagjaar 2009 Bilthoven: RIVM; 2009. 210021010/2009.

8. Rondy M, Van LA, de KJ V, Rust L, De MH: Determinants for HPV vaccine uptake in the Netherlands: A multilevel study. Vaccine 2010, 28(9):2070-2075.

9. Ensing E, Steen M, Laferte R, Zonnenberg I, De Hoogh P: Opkomst HPV-vaccinaties per 31 December 2010. Deel II van de rapportage: de ciffers. Bilthoven: RIVM; 2011.

10. Giesbers H, De Hoogh P: HPV (cohort 1997) per gemeente 2012. http://www. zorgatlas.nl/preventie/vaccinaties-en-screening/hpv-per-gemeente/.

11. Zwakhals SLN, Van Lier EA, Giesbers H: HPV (cohort 1998) per gemeente 2012. http://www.zorgatlas.nl/preventie/vaccinaties-en-screening/hpv-cohort1998-per-gemeente/\#breadcrumb].

12. Brewer NT, Fazekas Kl: Predictors of HPV vaccine acceptability: a theoryinformed, systematic review. Prev Med 2007, 45(2-3):107-114.

13. Katz IT, Ware NC, Gray G, Haberer JE, Mellins CA, Bangsberg DR: Scaling up human papillomavirus vaccination: a conceptual framework of vaccine adherence. Sex Health 2010, 7(3):279-286.

14. Zimet GD: Improving adolescent health: focus on HPV vaccine acceptance. J Adolesc Health 2005, 37(Suppl 6):17-23.

15. Zimet GD, Liddon N, Rosenthal SL, Lazcano-Ponce E, Allen B: Chapter 24: Psychosocial aspects of vaccine acceptability. Vaccine 2006, 24(Suppl 3):201-209.

16. Askelson NM, Campo S, Lowe JB, Smith S, Dennis LK, Andsager J: Using the theory of planned behavior to predict mothers' intentions to vaccinate their daughters against HPV. J Sch Nurs 2010, 26(3):194-202.

17. Barnack JL, Reddy DM, Swain C: Predictors of Parents' Willingness to Vaccinate for Human Papillomavirus and Physicians' Intentions to Recommend the Vaccine. Womens Health Issues 2010, 20(1):28-34.

18. Fahy A, Desmond DM: Irish mothers' intentions to have daughters receive the HPV vaccine. Ir J Med Sci 2010, 179(3):427-430.

19. Gerend MA, Weibley EBS, Bland HMD: Parental response to Human Papillomavirus Vaccine availability: Uptake and intentions. J Adolesc Health 2009, 45(5):528-531.

20. Reiter PL, Brewer NT, Gottlieb SL, McRee AL, Smith JS: Parents' health beliefs and HPV vaccination of their adolescent daughters. Soc Sci Med 2009, 69(3):475-480.

21. Brabin L, Roberts SA, Farzaneh F, Kitchener HC: Future acceptance of adolescent human papillomavirus vaccination: a survey of parental attitudes. Vaccine 2006, 24(16):3087-3094.

22. Dahlstrom LA, Tran TN, Lundholm C, Young C, Sundstrom K, Sparten P. Attitudes to HPV vaccination among parents of children aged 12-15 years - A population-based survey in Sweden. Int J Cancer 2010, 126(2):500-507.

23. Davis K, Dickman ED, Ferris D, Dias JK: Human papillomavirus vaccine acceptability among parents of 10- to 15-year-old adolescents. J Low Genit Tract Dis 2004, 8(3):188-194.

24. Dempsey AF, Zimet GD, Davis RL, Koutsky L: Factors that are associated with parental acceptance of human papillomavirus vaccines: a randomized intervention study of written information about HPV. Pediatrics 2006, 117(5):1486-1493.

25. Lazcano-Ponce E, Rivera L, Rillo-Santillan E, Salmeron J, Hernandez-Avila M, Munoz N: Acceptability of a human papillomavirus (HPV) trial vaccine among mothers of adolescents in Cuernavaca, Mexico. Arch Med Res 2001, 32(3):243-247.

26. Lenselink CH, Gerrits MM, Melchers WJ, Massuger LF, Van HD, Bekkers RL: Parental acceptance of Human Papillomavirus vaccines. Eur J Obstet Gynecol Reprod Biol 2008, 137(1):103-107.

27. Marlow LA, Waller J, Wardle J: Parental attitudes to pre-pubertal HPV vaccination. Vaccine 2007, 25(11):1945-1952.

28. Ajzen I: The theory of planned behavior. Organ Behav Hum Decis Process 1991, 50:179-211.

29. Bandura A: Social foundations of thought and action: A social cognitive theory. New York: Prentice Hall; 1986.

30. Becker MH: The health belief model and personal health behavior. Health Educ Monogr 1974, 30:324-508

31. Paulussen TGW, Lanting Cl, Buijs GB, Hirasing RA: Ouders over het Rijksvaccinatieprogramma: Tevredenheid en vaccinatiebereidheid van ouders van jonge kinderen in Nederland [Parents about the governments immunization program: Satisfaction and vaccine intention of Dutch parents of toddlers]. Leiden: TNO; 2000

32. Marlow LA, Waller J, Evans RE, Wardle J: Predictors of interest in HPV vaccination: A study of British adolescents. Vaccine 2009, 27(18):2483-2488.
33. Gerend MA, Lee SC, Shepherd JE: Predictors of human papillomavirus vaccination acceptability among underserved women. Sex Transm Dis 2007, 34(7):468-471.

34. Jacob M, Bradley J, Barone MA: Human papillomavirus vaccines: what does the future hold for preventing cervical cancer in resource-poor settings through immunization programs? Sex Transm Dis 2005, 32(10):635-640.

35. Verplanken B, Orbell S: Reflections on past behavior: A self-report index of habit strength. J App/ Soc Psychol 2003, 33:1313-1330.

36. O'Connor AM: Validation of a decisional conflict scale. Med Decis Mak 1995, 15(1):25-30

37. Riet J, Sijtsema SJ, Dagevos H, De Bruijn GJ: The importance of habits in eating behaviour. An overview and recommendations for future research. Appetite 2011, 57(3):585-596.

38. Schmitt N: Uses and abuses of coefficient alpha. Psychol Assess 1996, 8(4):350-353.

39. R Development Core Team: $R$ : A language and environment for statistical computing. Vienna: R Foundation for Statistical Computing; 2009.

40. Hastie T, Tibshirani R, Friedman J: The elements of statistical learning: Data mining, inference, and prediction. New York: Springer; 2001

41. Centraal Bureau voor de Statistiek: Sociale monitor. http://statline.cbs.nl/.

42. Centraal Bureau voor de Statistiek: Bevolking op 1 januari; leeftijd, geboorteland en regio. http://statline.cbs.nl/.

43. Centraal Bureau voor de Statistiek: Kerkelijke gezindte en kerkbezoek; vanaf 1849; 18 jaar of ouder. http://statline.cbs.nl/.

44. Paulussen TG, Hoekstra F, Lanting Cl, Buijs GB, Hirasing RA: Determinants of Dutch parents' decisions to vaccinate their child. Vaccine 2006, 24(5):644-651.

45. Herzog TJ, Huh WK, Downs LS, Smith JS, Monk BJ: Initial lessons learned in HPV vaccination. Gynecol Oncol 2008, 109(Suppl 2):4-11.

46. Lenselink CH, Schmeink CE, Melchers WJ, Massuger LF, Hendriks JC, Van HD, Bekkers RL: Young adults and acceptance of the human papillomavirus vaccine. Public Health 2008, 122(12):1295-1301.

47. Prislin R, Dyer JA, Blakely CH, Johnson CD: Immunization status and sociodemographic characteristics: the mediating role of beliefs, attitudes, and perceived control. Am J Public Health 1998, 88(12):1821-1826.

48. De Kok IMCM, Habbema JDF, Mourits MJE, Coebergh JWW, Van Leeuwen FE: Insufficient basis for the inclusion of Human papillomavirus vaccination in the National Immunisation Programme in the Netherlands. Ned Tijdschr Geneeskd 2008, 152(37):2001-2004.

49. Gerend MA, Magloire ZF: Awareness, knowledge, and beliefs about human papillomavirus in a racially diverse sample of young adults. J Adolesc Health 2008, 42(3):237-242.

50. Ziarnowski KL, Brewer NT, Weber B: Present choices, future outcomes: anticipated regret and HPV vaccination. Prev Med 2009, 48(5):411-414.

51. Loosveldt $\mathrm{G}$, Sonck $\mathrm{N}$ : An evaluation of the weighting procedures for an online access panel survey. Surv Res Meth 2008, 2(2):93-105.

52. Zwakhals SLN, Van Lier EA, Giesbers H: HPV-inhaalcampagne (cohort 1993-1996) per gemeente 2011. http:/www.zorgatlas.n//preventie/vaccinaties-en-screening/ hpv-inhaalcampagne-per-gemeente-2010\%

53. Hontelez JAC, Hahné SJM, Oomen P, de Melker H: Parental attitude towards childhood HBV vaccination in The Netherlands. Vaccine 2010, 28(4):1015-1020

54. Manfreda KL, Bosnjak M, Berzelak J, Haas I, Vehovar V: Web surveys versus other survey modes: A meta-analysis comparing response rates. Int J Market Res 2008, 50(1):79-104.

55. Shih $\mathrm{TH}$, Xitao $\mathrm{F}$ : Comparing response rates from web and mail surveys: A meta-analysis. Field Methods 2008, 20(3):249-271.

56. Edwards PJ, Roberts I, Clarke MJ, Diguiseppi C, Wentz R, Kwan I, Cooper R, Felix LM, Pratap S: Methods to increase response to postal and electronic questionnaires. Cochrane Database Syst Rev 2009, 3:MR000008.

57. McCluskey S, Topping AE: Increasing response rates to lifestyle surveys: a pragmatic evidence review. Perspect Public Health 2011, 131(2):89-94.

58. Krebs P, Prochaska JO, Rossi JS: A meta-analysis of computer-tailored interventions for health behavior change. Prev Med 2010, 51(3-4):214-221.

59. Noar SM, Benac CN, Harris MS: Does tailoring matter? Meta-analytic review of tailored print health behavior change interventions. Psychol Bull 2007, 133(4):673-693.

doi:10.1186/1471-2458-13-111

Cite this article as: van Keulen et al: Determinants of HPV vaccination intentions among Dutch girls and their mothers: a cross-sectional study. BMC Public Health 2013 13:111. 